University of Wollongong

Research Online

Faculty of Science, Medicine and Health -

Papers: Part B

Faculty of Science, Medicine and Health

$1-1-2019$

\title{
High resolution geochemical analysis of massive Porites spp. corals from the Wet Tropics, Great Barrier Reef: rare earth elements, yttrium and barium as indicators of terrigenous input
}

\author{
Nicole Leonard \\ University of Queensland \\ $\mathrm{K}$ J. Welsh \\ University of Queensland \\ Ai Duc Nguyen \\ University of Queensland \\ J Sadler \\ University of Queensland \\ John M. Pandolfi \\ University of Queensland \\ See next page for additional authors
}

Follow this and additional works at: https://ro.uow.edu.au/smhpapers1

\section{Publication Details Citation}

Leonard, N., Welsh, K. J., Nguyen, A., Sadler, J., Pandolfi, J. M., Clark, T. R., Zhao, J. -., Feng, Y., \& Webb, G. E. (2019). High resolution geochemical analysis of massive Porites spp. corals from the Wet Tropics, Great Barrier Reef: rare earth elements, yttrium and barium as indicators of terrigenous input. Faculty of Science, Medicine and Health - Papers: Part B. Retrieved from https://ro.uow.edu.au/smhpapers1/969

Research Online is the open access institutional repository for the University of Wollongong. For further information contact the UOW Library: research-pubs@uow.edu.au 


\title{
High resolution geochemical analysis of massive Porites spp. corals from the Wet Tropics, Great Barrier Reef: rare earth elements, yttrium and barium as indicators of terrigenous input
}

\author{
Abstract \\ Catchment modification and increased sediment loads in coastal regions are impacting many of the \\ world's coral reefs, yet relevant water quality data are limited by the availability of instrumental records. \\ Massive Porites spp. corals offer the potential to reconstruct water quality by use of the geochemical \\ proxies that are incorporated into their skeleton. Here we present $\sim$ monthly resolved rare earth element \\ $(\mathrm{REE})$, yttrium $(\mathrm{Y})$ and barium/calcium $(\mathrm{Ba} / \mathrm{Ca}$ ) concentrations obtained from four Porites corals collected \\ across a known water quality gradient from the Great Barrier Reef, Australia. Sub-annual REE time series \\ patterns were comparable among corals despite having significantly different concentrations. Whilst $\mathrm{Ba} /$ \\ Ca did not reflect the known water quality gradient of the region, $\mathrm{Y} / \mathrm{holmium}$ ratios reflected broad cross \\ shelf water quality gradients and REE concentrations reflected local scale variance in water quality. This \\ study demonstrates that REE analysis of Porites corals offers great potential for assessing changes in \\ water quality in reef environments.

\section{Publication Details} \\ Leonard, N. D., Welsh, K. J., Nguyen, A. D., Sadler, J., Pandolfi, J. M., Clark, T. R., Zhao, J., Feng, Y. \& Webb, \\ G. E. (2019). High resolution geochemical analysis of massive Porites spp. corals from the Wet Tropics, \\ Great Barrier Reef: rare earth elements, yttrium and barium as indicators of terrigenous input. Marine \\ Pollution Bulletin, 149 110634-1-110634-12.

\section{Authors} \\ Nicole Leonard, K J. Welsh, Ai Duc Nguyen, J Sadler, John M. Pandolfi, Tara R. Clark, J -X Zhao, Yue-xing \\ Feng, and Gregory E. Webb
}




\title{
High resolution geochemical analysis of massive Porites spp. corals from the Wet Tropics, Great Barrier Reef; rare earth elements, yttrium and barium as indicators of terrigenous input
}

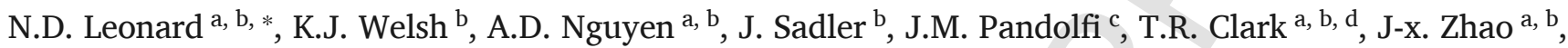 \\ Y-x Feng ${ }^{\text {a, b }}$, G.E. Webb ${ }^{b}$ \\ ${ }^{a}$ Radiogenic Isotope Facility, School of Earth and Environmental Sciences, The University of Queensland, Brisbane, Qld, 4072, Australia \\ ${ }^{\mathrm{b}}$ School of Earth and Environmental Sciences, The University of Queensland, Brisbane, Qld, 4072, Australia \\ ${ }^{c}$ Centre for Marine Science, Australian Research Council Centre of Excellence for Coral Reef Studies, School of Biological Sciences, The University of Queensland, Brisbane, Qld, 4072, Australia \\ d School of Earth \& Environmental Sciences, Faculty of Science, Medicine \& Health, University of Wollongong NSW, 2522, Australia
}

\section{A R T I C LE INFO}

\section{Keywords:}

Rare earth elements

Yttrium

Barium/calcium

Coral geochemical proxies

Great Barrier Reef

Water quality

\begin{abstract}
A B S T R A C T
Catchment modification and increased sediment loads in coastal regions are impacting many of the world's coral reefs, yet relevant water quality data are limited by the availability of instrumental records. Massive Porites spp. corals offer the potential to reconstruct water quality by use of the geochemical proxies that are incorporated into their skeleton. Here we present $\sim$ monthly resolved rare earth element (REE), yttrium (Y) and barium/calcium $(\mathrm{Ba} / \mathrm{Ca})$ concentrations obtained from four Porites corals collected across a known water quality gradient from the Great Barrier Reef, Australia. Sub-annual REE time series patterns were comparable among corals despite having significantly different concentrations. Whilst $\mathrm{Ba} / \mathrm{Ca}$ did not reflect the known water quality gradient of the region, $\mathrm{Y} /$ Holmium ratios reflected broad cross shelf water quality gradients and REE concentrations reflected local scale variance in water quality. This study demonstrates that REE analysis of Porites corals offers great potential for assessing changes in water quality in reef environments.
\end{abstract}

\section{Introduction}

Recognised as a World Heritage Area, the Great Barrier Reef (GBR) is the largest contiguous coral reef system in the world (Hopley, 1982). However, increasing anthropogenic pressure (sedimentation, agricultural nutrient run-off, coastal development) combined with global climate change (e.g. increasing temperatures and intensity of tropical cyclones) has contributed to a substantial decline in coral cover in recent decades (De'ath et al., 2012; Hughes et al., 2015; Pandolfi et al., 2003). Understanding both climatic and environmental conditions that affected coral reef growth and reef ecology in the recent geological past is thus invaluable for improving predictions of future responses (Pandolfi, 2015). Following extensive land clearing since European settlement of the Queensland coast, increased fluvial sediment delivery, and consequently increased coastal turbidity to the GBR, has been cited as a major control on reef health and community composition, especially at inshore locations. However, deriving water quality baselines prior to instrumental monitoring is challenging (De'ath and Fabricius, 2010).

Long-lived, annually banded massive corals provide a unique opportunity for high resolution reconstruction of past environmental and climatic conditions by use of both luminescent bands (Isdale et al., 1998; Lough et al., 2014; Rodriguez-Ramirez et al., 2014) and geochemical proxies that are incorporated into the coral skeleton during growth (see Saha et al., 2016 and references therein). Visible under ultra violet (UV) light, luminescent bands in sliced sections of massive Porites coral cores have been shown to be robust indicators of river discharge at nearshore locations on the GBR (Isdale, 1984; Isdale et al., 1998; Lough et al., 2002; Lough, 2011a), thereby providing a tool for quantifying river flow prior to instrumental records (Lough et al., 2015). Luminescence records also have been used to infer longer term climatic drivers of Australian rainfall, such as the El Niño Southern Oscillation (ENSO) (e.g. Hendy et al., 2003; Leonard et al., 2016; Lough et al., 2014) and the Pacific Decadal Oscillation (PDO) (Rodriguez-Ramirez et

\footnotetext{
* Corresponding author. Radiogenic Isotope Facility, School of Earth and Environmental Sciences, The University of Queensland, Brisbane, Qld, 4072, Australia.

Email address: n.leonard@uq.edu.au (N.D. Leonard)
} 


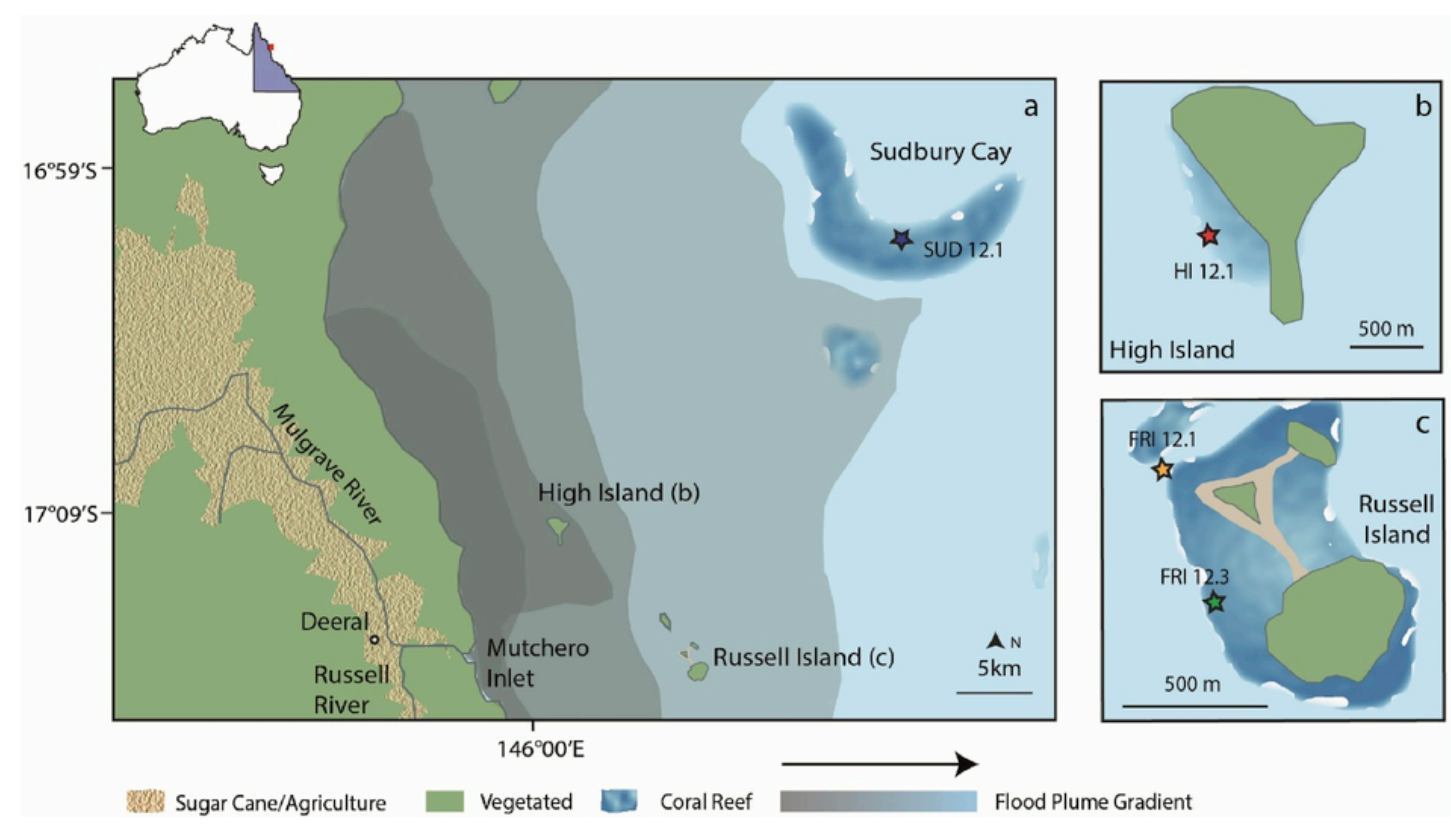

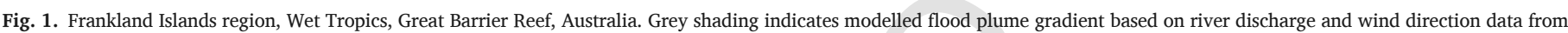

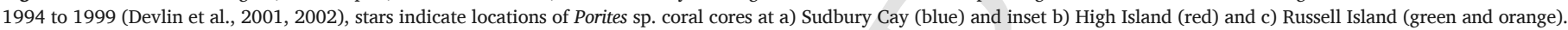
(For interpretation of the references to colour in this figure legend, the reader is referred to the Web version of this article.)

al., 2014). However, luminescent bands do not allow quantification of ambient seawater chemistry or flood plume characteristics associated with high discharge/rainfall events (McCulloch et al., 2003). Consequently, trace elements and isotopic signatures incorporated into the skeletal lattice during coral growth are commonly used to reconstruct past seawater conditions (see Saha et al., 2016 for review). Yet, for geochemical proxies to be used reliably in palaeoenvironmental reconstructions, it is first necessary to demonstrate both the alignment of instrumental data with geochemical proxy data, and to demonstrate the reproducibility of geochemical signals at local to regional scales (Prouty et al., 2008).

The most commonly reported proxy for riverine sediment input onto the GBR is Barium (Ba), which is desorbed from fine suspended sediments at low salinities in the estuarine mixing zone, and therefore acts as a dissolved tracer of flood plumes reaching reefs (e.g. Lewis et al., 2012; McCulloch et al., 2003; Sinclair and McCulloch, 2004). An estimated 5-10 fold increase in fluvial sediment delivery to the GBR since European settlement was inferred from $\mathrm{Ba} / \mathrm{Ca}$ baseline levels in the Burdekin River region (McCulloch et al., 2003) and peaks in $\mathrm{Ba} / \mathrm{Ca}$ have been found to correspond well with instrumental records of high rainfall/river flow events (Sinclair and McCulloch, 2004; Walther et al., 2013; Wyndham et al., 2004). However, a 250-year coral record from Havannah Island (GBR) showed that peaks in $\mathrm{Ba} / \mathrm{Ca}$ did not align with luminescent bands prior to European settlement, correlating only with luminescence and known flood events after anthropogenic influence increased (McCulloch et al., 2003). High magnitude Ba/Ca peaks decoupled from river discharge events also have been reported from elsewhere on the GBR (Jupiter et al., 2008; Saha et al., 2018a; Sinclair, 2005) and replicate coral records have shown poor correlation of geochemical signals both within and between sites (Lewis et al., 2012, 2018). Hence, the exact drivers of Ba concentrations in local seawaters are complex, but biological mediation in the water column (Elliot et al., 2009; Lewis et al., 2007; Saha et al., 2018b; Sinclair, 2005; Tanzil et al., 2019), release of Ba from hyper-saline mangrove zones (Moyer, 2012; Prouty et al., 2010) or sub-marine ground water seeps (Alibert et al., 2003) and upwelling (Lea et al., 1989; Montaggioni et al., 2006) have all been proposed for different regions.
In contrast with Ba, Yttrium (Y), which is not biologically mediated, has been shown to be a more conservative proxy for fine suspended sediments across water quality gradients at annual or longer timescales (Alibert et al., 2003; Jupiter et al., 2008; Lewis et al., 2012, 2018), but is seemingly less reliable at sub-annual resolution (Moyer, 2012; Prouty et al., 2010; Saha et al., 2018a). In the Palm Islands region (GBR), average coral $\mathrm{Y}$ concentrations were found to be six times higher at inshore versus mid-shelf sites (Alibert et al., 2003) although no correlation was found between $\mathrm{Y} / \mathrm{Ca}$ and coral luminescence or river discharge (Lewis et al., 2018). Conversely, positive correlations between annual mean Y/ Ca values and luminescent band intensity were reported in the Whitsundays, although, again, inter-annual Y/Ca was not significantly correlated with either river discharge or luminescence (Lewis et al., 2012).

The rare earth elements (REEs) offer potential as a proxy for reconstructing rainfall/flood events and turbidity as $~ 90 \%$ of REEs in coastal waters are derived from suspended and dissolved riverine input (Dubinin, 2004). Rare earth elements are incorporated into the coral skeleton relative to ambient sea water chemistry at the time of growth (Akagi et al., 2004; Sholkovitz and Shen, 1995; Wyndham et al., 2004). Yet, compared with $\mathrm{Ba}$ and $\mathrm{Y}$, high resolution (sub-annual) records of REEs in corals are relatively few (Fallon and McCulloch, 2002; Naqvi et al., 1996; Nguyen et al., 2013; Saha et al., 2019), and only three records of REEs in corals from the GBR are currently available (Jupiter, 2008; Saha et al., 2019; Wyndham et al., 2004). In the Central GBR Wyndham et al. (2004) reported total rare earth element ( $\Sigma$ REE) concentrations over ten times higher in corals from inshore sites compared to the mid-shelf, reflecting the terrestrial influence of Burdekin River discharge. In the southern Central GBR $\Sigma$ REE concentrations increased 4-fold along an inner-to outer-shelf gradient (Jupiter, 2008). At Magnetic Island, again under the influence of the Burdekin River, Saha et al. (2019) presented a single coral 26-year record where peaks in REEs and yttrium (REYs) concentrations correlated with river discharge, rainfall and measured turbidity at annual or longer timescales, although limitations were noted at sub-annual scales.

As well as total concentrations of REYs, hydrogenous REY concentrations can be normalised against known terrestrial (shale) upper crust REY values (in this case MUd of Queensland; Kamber et al., 2005). This 


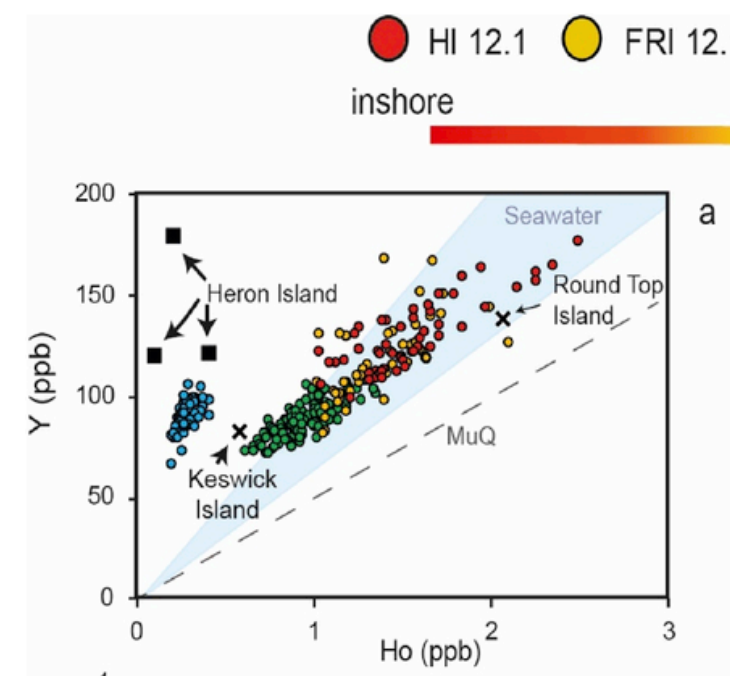

a
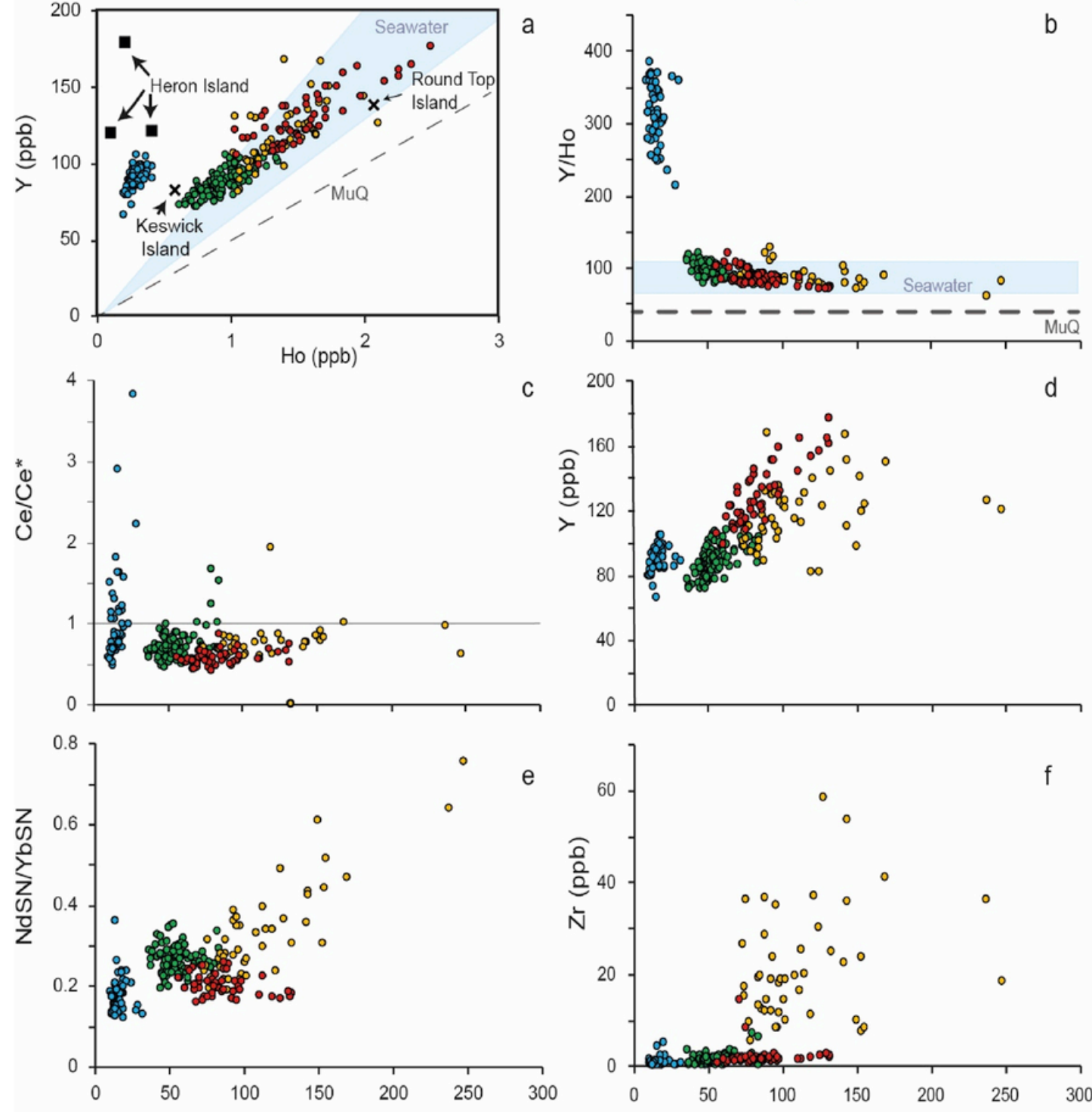

e

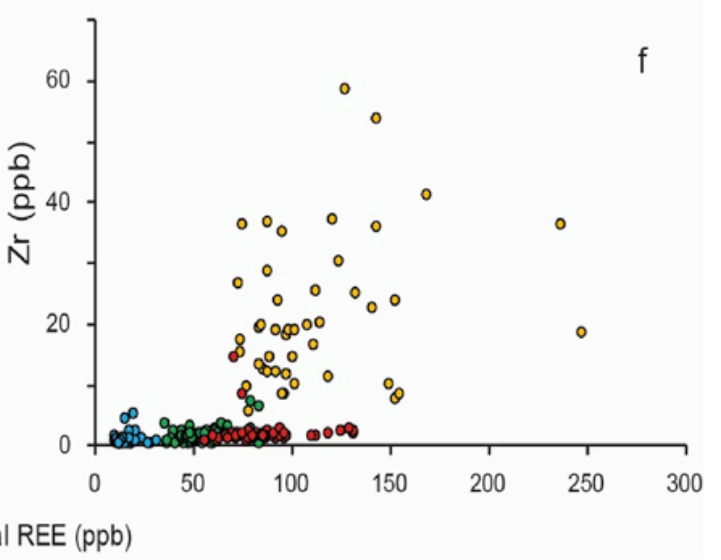

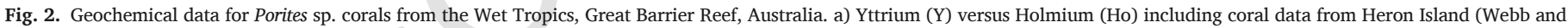

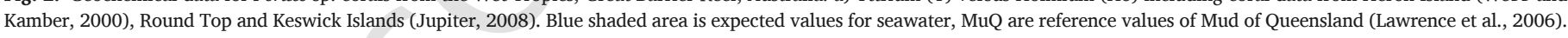

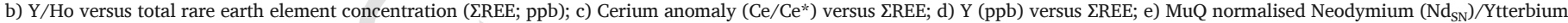
$\left(\mathrm{Yb}_{\mathrm{SN}}\right)$ versus $\Sigma \mathrm{REE}$; and $\mathrm{f}$ ) Zirconium (Zr) versus $\Sigma \mathrm{REE}$. (For interpretation of the references to colour in this figure legend, the reader is referred to the Web version of this article.)

allows for recognition of terrigenous sediment-derived contributions in coastal seawater owing to differential behaviour of dissolved REYs. In the estuarine mixing zone the larger ionic radii of the light rare earth elements (LREEs; La-Nd) causes them to be preferentially adsorbed onto larger Fe-organic and salt-enriched colloids in seawater (Elderfield et al., 1990; Hoyle et al., 1984), compared with $~ 70 \%$ of the heavy REEs (HREEs; Tb-Lu) with particles $<0.4 \mu \mathrm{m}$ (Hoyle et al., 1984). Therefore flocculation of particles and their removal from the water column will result in LREE depletion in seawater. This can determined by $\mathrm{Nd}_{\mathrm{SN}} / \mathrm{Yb}_{\mathrm{SN}}$ ratios $<1$ (where ${ }_{\mathrm{SN}}$ indicates shale normalised). In addition oxidation of $\mathrm{Ce}^{3+}$ to insoluble $\mathrm{Ce}^{4+}$ and subsequent removal from the water column by particulate scavenging will result in a neg- ative Ce anomaly relative to other LREEs. Furthermore, although $\mathrm{Y}$ and Ho are considered a geochemical pair due to nearly identical ionic radii and charge (Lawrence et al., 2006b), Ho is scavenged twice as fast as $\mathrm{Y}$ in the estuarine mixing zone at relatively low salinities [5.5\%o (Lawrence and Kamber, 2006; Nozaki et al., 1997)]. Hence, open seawater has a superchondritic Y/Ho ratio, whilst lower Y/Ho ratios reflect less scavenging and thus are consistent with terrigenous flux (i.e. fluvial plumes). The resulting pattern of shale normalised REYs for shallow seawater is therefore characterised by LREE depletion, a super-chondritic Y/Ho ratio and negative Ce anomaly, whereas regions effected by high terrestrial input display a flatter (i.e. less LREE depleted) shale-normalised REY profile. 


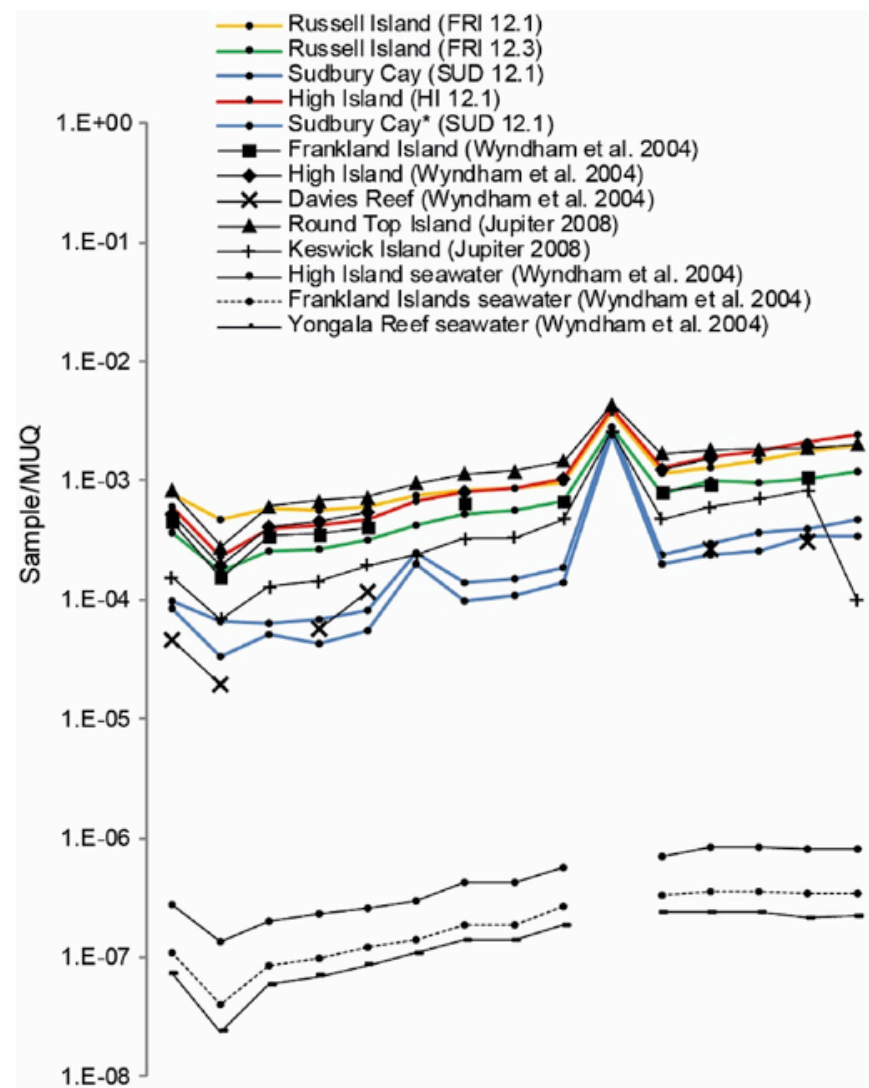

La Ce Pr Nd Sm Eu Gd Tb Dy Y Ho Er Tm Yb Lu

Fig. 3. Average Mud of Queensland [MUQ; Kamber et al., (2005) normalised REE and Yttrium (REY) data from four Porites spp. coral colonies from the Wet Tropics, Great Barrier Reef (GBR), compared with previously reported coral and sea water data from the GBR.

To further investigate the utility of REYs in high resolution palaeoclimatic and broad scale palaeoenvironmental reconstructions over larger spatial scales we present the results of $\sim$ monthly resolved REE, Y and Ba concentration data obtained from four modern Porites spp. coral cores collected across a known water quality gradient from the inshore to mid-shelf near the Frankland Islands, GBR. Time-resolved geochemical proxy data from these cores are compared to instrumental records of river discharge, rainfall and flood plume frequency in the adjacent Wet Tropics Queensland coast. This allows us to test the utility of coral-based REY proxies for use in more spatially resolved palaeo-environmental reconstructions.

\section{Materials and methods}

\subsection{Location and environmental setting}

The Frankland Islands and Sudbury Cay are located off the north-east coast of Queensland's Wet Tropics region, GBR, Australia (Fig. 1a). The Frankland Islands group consists of five continental islands (High, Russell, Normanby, Mabel and Round Islands), which support fringing reefs to the leeward and windward. These islands are all within $\sim 10 \mathrm{~km}$ of the coast and are influenced by the Russell and Mulgrave Rivers, which discharge into the GBR lagoon via the Mutchero Inlet (Fig. 1a). Flood plume frequency analysis in the Frankland Islands derived from satellite imagery and modelled from river discharge data, demonstrates that plumes (generated from river discharge events of $30000 \mathrm{MLd}^{-1}$ ) are typically advected north by the predominant south-easterly trade winds as well as Coriolis forces (Devlin et al., 2001,
2002). Consequently, High Island is influenced more often by river discharge events than is Russell Island, although both sites are impacted by river flood plumes annually. Flood plumes were estimated to impact Sudbury Cay on the mid-shelf ( $\sim 32 \mathrm{~km}$ north east of the Russell-Mulgrave River system) only once every 4-6 years (Fig. 1; Devlin et al., 2002; Devlin et al., 2001).

Annual rainfall is seasonal with more than $60 \%$ falling in the austral summer (December-March) with a rainfall to runoff conversion of $\sim 60 \%$ (Connolly et al., 2007). The lower coastal catchment areas of both the Russell and Mulgrave rivers have been modified to accommodate predominantly sugar-cane, with grazing, fruit crops and other minor horticultural activities also within the region (Connolly et al., 2007; Furnas, 2003). Within the catchments, the lowland tributaries of the Russell River are significantly degraded due to the removal of riparian vegetation leading to bank destabilisation, and subsequently, higher sediment loads than the Mulgrave River (Arthington et al., 2007).

\subsection{Coral core collection, treatment and sampling}

Coral cores were collected from living massive Porites spp. coral colonies ( $>1.5 \mathrm{~m}$ diameter) in November 2012 using a pneumatic drill with a $5 \mathrm{~cm}$ barrel attachment on SCUBA at $\sim 5 \mathrm{~m}$ water depth on the leeward side of Russell (FRI 12.1, FRI 12.3) and High (HI 12.1) Islands, and within the lagoon at Sudbury Cay (SUD 12.1; Fig. 1). Cores were rinsed in fresh water and air dried before transportation. Cores were cut along the growth axis into $6 \mathrm{~mm}$ thick slabs at the School of Earth and Environment, University of Western Australia. Sections were ultra-sonicated three times in Milli-Q water for $15 \mathrm{~min}$ and dried in an oven at $60^{\circ} \mathrm{C}$. Core sections were X-rayed at St Vincent's hospital, Brisbane, to determine growth axis and chronology based on density band counting. Coral slabs were also viewed under ultra violet light to allow visualisation of luminescent bands.

Based on daily river discharge data from the Department of Natural Resources and Mines(https://www.dnrm.qld.gov.au/water/water-monitoring-and-data; 1980 - present) for the Russell (Station Number 111101D), Mulgrave (111007A) and South Johnstone rivers (112101B), as well as daily rainfall data from Deeral (1929 - present; Station 031021; http://www.bom.gov.au/climate/data/; Fig. 1), periods of both low and high rainfall/river discharge were selected for analysis to allow assessment of the response of geochemical signals in the coral cores. To test whether REE concentrations could be used to reconstruct ambient water quality conditions the period 2001-2002, identified as having the lowest river runoff, was selected to ascertain "baseline" REE levels in all four cores. Periods of increased discharge bracket this period and corals were sampled prior to (HI 12.1, FRI 12.1, SUD 12.1) and after (HI 12.1, FRI 12.3, SUD 12.1) 2001-2002 (Supp. Fig. 1). To capture the entire record spanning $\sim 2000-2006,5-10 \mathrm{~cm}$ sections of each coral were selected with overlap in time series between the cores. One annual band from the base of coral FRI 12.1 ( 1950) was also sampled to allow for comparison with modern values. Approximately $5 \mathrm{mg}$ of aragonite was milled across the coral cores at $\sim 1 \mathrm{~mm}$ increments following sub-annual (lunar; $\sim$ monthly resolution) banding (DeCarlo and Cohen, 2017; Taylor et al., 1993) along the primary growth axis using a hand held Dremel drill with a flexible shaft extension and $1 \mathrm{~mm}$ diamond tip bit (Supp. Fig 1). To eliminate sample cross-contamination, coral cores were cleaned with compressed air between each sample and a new drill bit was used between every sample.

As trace elements can be incorporated through the depth of the living tissue layer, both extension rate and tissue thickness can affect sub-annual geochemical signals in corals (Nothdurft et al., 2007; Taylor et al., 1995). Therefore, the ratio of tissue thickness (measured directly from the core top) relative to linear extension (measured from X-ray 


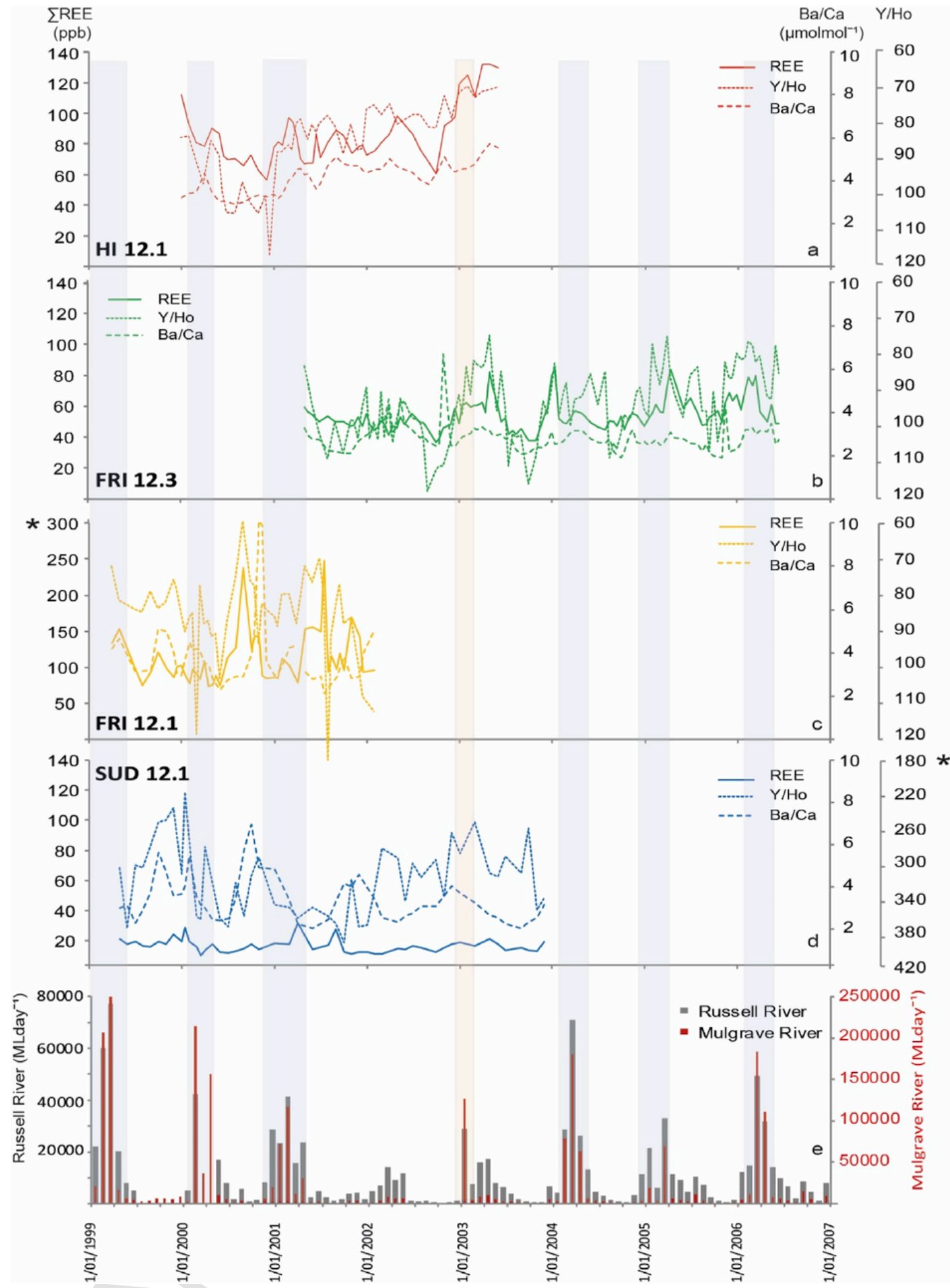

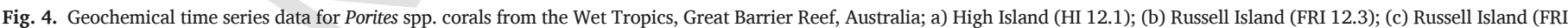

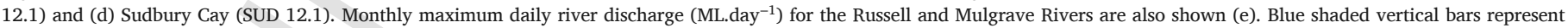

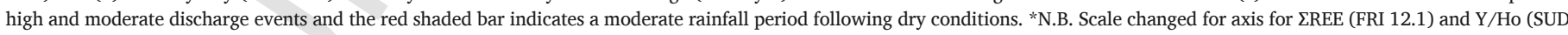
12.1). (For interpretation of the references to colour in this figure legend, the reader is referred to the Web version of this article.)

positive images) was used to calculate the potential month equivalent by which geochemical signals may be averaged from a causative discharge event.

\subsection{Geochemical procedures}

Major and trace elements were measured at the Radiogenic Isotope Facility, The University of Queensland. Approximately $2 \mathrm{mg}$ of each powdered sample was weighed on a five-digit scale and transferred to 


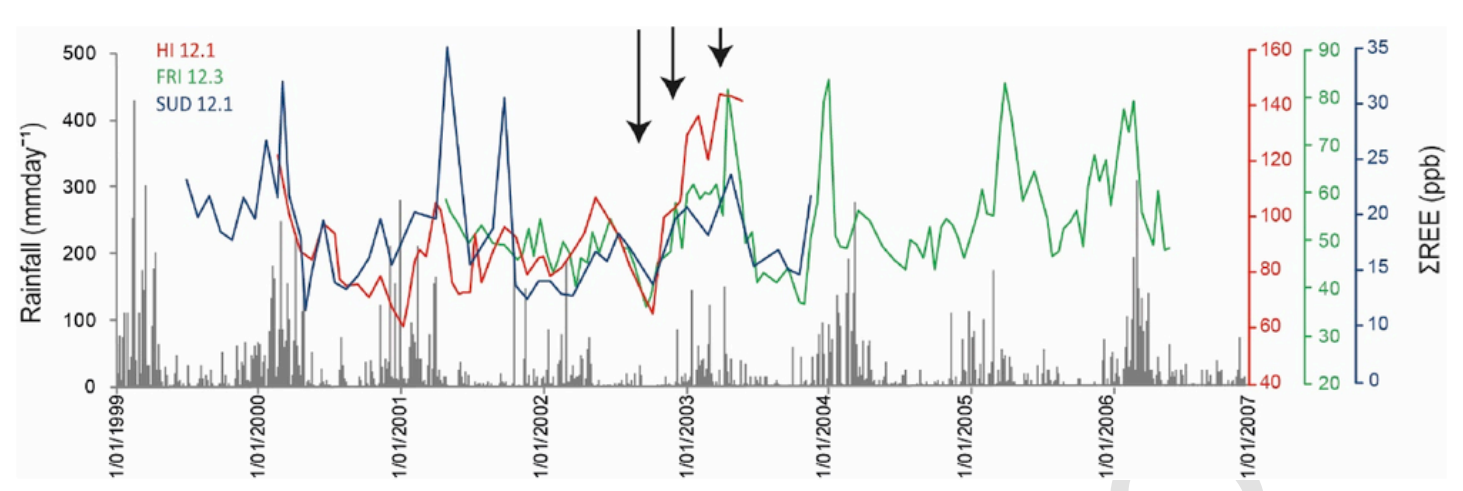

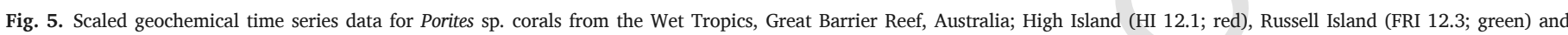

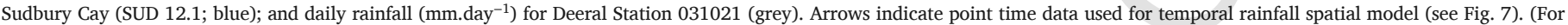
interpretation of the references to colour in this figure legend, the reader is referred to the Web version of this article.)

ultra-cleaned $5 \mathrm{ml}$ Teflon tubes. Samples were dissolved in $\sim 4.5 \mathrm{ml}$ (weighed) $2 \% \mathrm{HNO}_{3}$ containing $6 \mathrm{ppb}$ concentrations of internal standards of ${ }^{6} \mathrm{Li},{ }^{45} \mathrm{Sc},{ }^{103} \mathrm{Rh},{ }^{115} \mathrm{In},{ }^{187} \mathrm{Re},{ }^{207} \mathrm{Bi}$ and ${ }^{235} \mathrm{U}$ to achieve a final sample dilution factor of $\sim 2500$. Stock solutions of certified standards W2a (USGS Diabase), BIR-1 (Basalt) and BHVO-2 (Basalt) were weighed and diluted using the same internal standard solution to a final dilution factor of $\sim 5000$. The coral standard JCp-1 (Okai et al., 2002) was similarly prepared to a final dilution factor of $\sim 2500$. All samples and standards were ultra-sonicated for $30 \mathrm{~min}$ to ensure complete digestion and homogenisation of the solutions, after which they were centrifuged at $3500 \mathrm{rpm}$ for $15 \mathrm{~min}$ immediately prior to measurement on a Thermo X-series II Quadrupole Inductively Coupled-Mass Spectrometer (ICP-MS). Samples were run over four batches of 100 samples each, with one-half of FRI 12.3 samples run in batch 1 and the other half in batch 4 to check for trace element matching. Elemental count rates were corrected for any internal and external drift and oxide interferences. The corrected elemental count rates were then used to calibrate against the W-2 (Diabase) standard to calculate elemental concentrations, except for $\mathrm{Ca}, \mathrm{Ba}$, and $\mathrm{Sr}$, which were calibrated using the JCp-1 (coral) standard. JCp-1 values for Ba and calibration were based on the average W2a-1 corrected values for the four batches $(n=12)$, whereas values for $\mathrm{Ca}, \mathrm{Sr}$ and $\mathrm{U}$ for $\mathrm{JCp}-1$ were obtained from Georem (http://georem.mpch-mainz.gwdg.de/) using the values of Aizawa (2008) and Okai (2002). Additional information about reproducibility and standardisation of REY values using our approach can be found in Saha et al. (2019).

\subsection{Geochemical analysis}

Monthly in situ sea surface temperature (SST) data from the Frankland Islands and Arlington Reef (Australian Institute of Marine Science) were used to bracket sub-annual chronology assignment, using the peaks and troughs of the Sr/Ca signal (measured simultaneously) with the coldest months assigned to July-August (highest $\mathrm{Sr} / \mathrm{Ca}$ ) and the warmest months assigned to January-February,. Normality of the data for the overlapping time period between the four coral core geochemical records (05/2001-02/2002) for $\Sigma$ REE, Y/Ho, $\mathrm{Nd}_{\mathrm{SN}} / \mathrm{Yb}_{\mathrm{SN}}$ and $\mathrm{Ba} / \mathrm{Ca}$ were tested using Shapiro-Wilk test. Parametric data were compared by analysis of variance (ANOVA-with unequal variance) and Tukey's post hoc test was used to detect differences in mean concentration between the cores. Non-parametric data were transformed using Box-Cox transformation to normalise, and if successful analysed by ANOVA and Tukey's. Non-parametric data was tested for variance of the median using Kruskal-Wallis test and differences were checked using a Mann-Whitney. All statistical operations were performed in the PAST statistical package (Hammer et al., 2001).
Rare earth element and Y data were normalised using Mud of Queensland (MuQ) values of Kamber et al. (2005) to examine element distribution patterns between cores. Cerium and europium anomalies (i.e., the deviation of the measured MuQ normalised value $\left[\mathrm{REE}_{\mathrm{SN}}\right]$ compared to the predicted value of the REE derived from neighbouring lanthanides $\left[\mathrm{REE}_{\mathrm{SN}^{*}}{ }^{*}\right]$ ), was calculated using the equations of Lawrence et al. (2006a):

$$
\text { for Ce; } \mathrm{Ce}_{\mathrm{SN}} / \mathrm{Ce}_{\mathrm{SN}} *=\mathrm{Ce}_{\mathrm{SN}} /\left(\mathrm{Pr}_{\mathrm{SN}} *\left(\mathrm{Pr}_{\mathrm{SN}} / \mathrm{Nd}_{\mathrm{SN}}\right)\right)
$$

for Europium;

$$
\mathrm{Eu}_{\mathrm{SN}} / \mathrm{Eu}_{\mathrm{SN}} *=\mathrm{Eu}_{\mathrm{SN}} /\left(\mathrm{Sm}_{\mathrm{SN}}{ }^{2} * \mathrm{~Tb}_{\mathrm{SN}}\right)^{0.33}
$$

Water quality gradients were reconstructed using a kriging spatial interpolation model in the PAST statistical package (Hammer et al., 2001) using average concentration data (05/2001-02/2002) for $\Sigma$ REE, $\mathrm{Y} / \mathrm{Ho}, \mathrm{Nd}_{\mathrm{SN}} / \mathrm{Yb}_{\mathrm{SN}}$ and $\mathrm{Ba} / \mathrm{Ca}$ for each core plotted in latitudinal-longitudinal space. Time series of a low to high rainfall/discharge event also were plotted spatially for $\mathrm{REEE}$ using the same kriging model and parameters in the PAST statistical programme (Hammer et al., 2001).

\section{Results}

\subsection{Core chronology and growth characteristics}

$\mathrm{X}$-ray positive images showed clear annual density bands in all four cores, although the rates of linear extension and tissue thickness of each colony varied (Supp. Tbl. 1). Average linear extension was highest in FRI $12.3\left(2.10 \pm 0.19 \mathrm{cmyr}^{-1}\right)$ compared to FRI $12.1(1.59 \pm 0.21$ $\left.\mathrm{cmyr}^{-1}\right)$, HI $12.1\left(1.66 \pm 0.23 \mathrm{cmyr}^{-1}\right)$ and SUD $12.1(1.18 \pm 0.15$ $\mathrm{cmyr}^{-1}$ ). Colony FRI 12.3 also had the lowest average tissue thickness/ linear extension ratio (0.29), resulting in an approximated possible time averaging of the geochemical signal of $\sim 3$ months. Core FRI 12.1 displayed the highest possible ratio equivalent to $\sim 7$ months-time averaging due to the relative thick living tissue layer $(0.9 \mathrm{~cm})$ relative to the average linear extension rate.

Viewed under UV light, the annual luminescence bands in the three inshore corals were well matched (Supp. Fig. 1), with a distinct double band observed in the three nearshore corals in 2000, corresponding to two major discharge events in the Mulgrave River (February and April). This double band event was not as clear in SUD 12.1 (mid-shelf), but still detectable. Visual assessment of luminescence intensity was relatively weak in all the corals for 2001-2002, which agrees well with lower overall discharge in the region for the same period (Supp. Fig. 1). The coherency between the luminescent bands of the four cores confirms the annual chronology based on density band counting. 

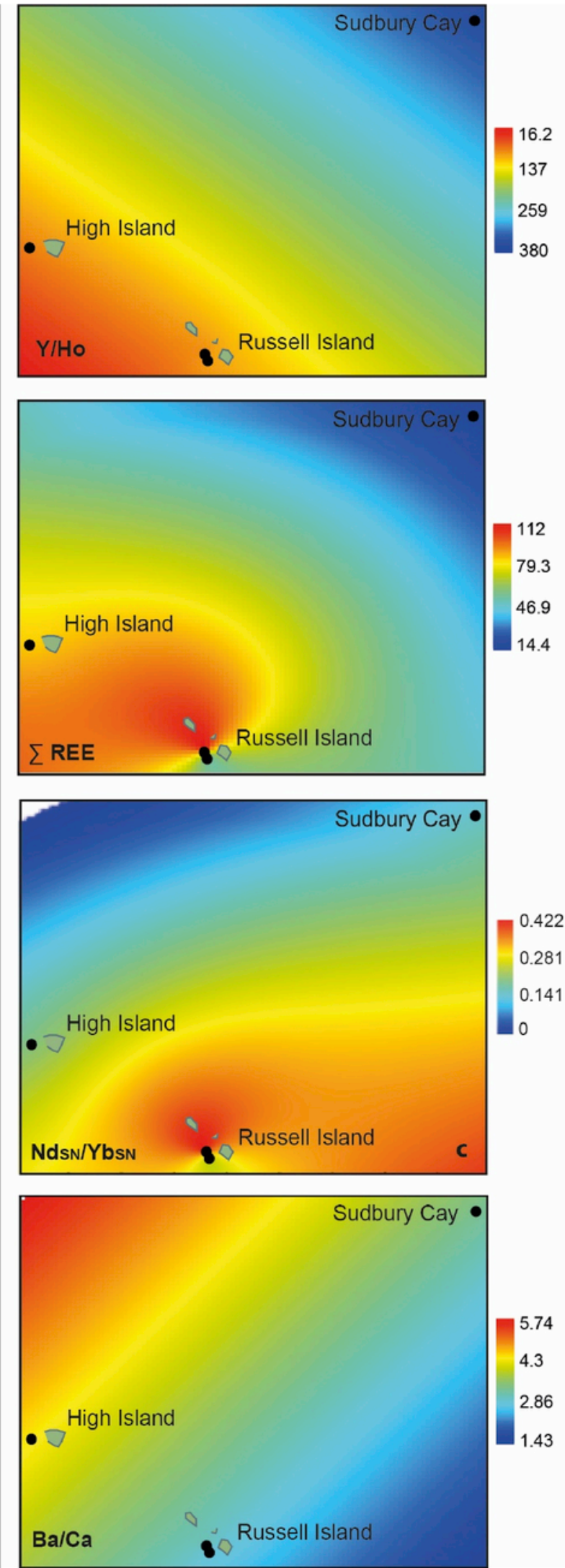

Fig. 6. Gridded spatial interpolation (kriging) model of average (May 2001-Feb 2002) geochemical data derived from four Porites sp. coral cores in the Wet Tropics, Great Barrier Reef, Australia; a) Yttrium/Holmium $(\mathrm{Y} / \mathrm{Ho})$; b) total rare earth element ( $\Sigma \mathrm{REE}-$ $\mathrm{ppb})$; c) shale normalised $\mathrm{Nd} / \mathrm{Yb}$ ratio $\left(\mathrm{Nd}_{\mathrm{SN}} / \mathrm{Yb}_{\mathrm{SN}}\right)$; and d) Barium/Calcium (Ba/Ca; $\mu$ mol$\left.\mathrm{mol}^{-1}\right)$.

\subsection{Trace element geochemistry}

Average W2a-1 calibrated concentrations of geochemical reference materials BHVO-2 and BIR-1 run over four batches were in agreement with certified values (Supp. Tbl 2). Calculated $\mathrm{Ba} / \mathrm{Ca}$ and $\mathrm{Sr} / \mathrm{Ca}$ ratio values for coral standard JCp-1 $(n=9)$ were $7.746 \pm 0.082 \mu$ molmol-1 and $8.695 \pm 0.069 \mu$ molmol-1, respectively, which are within error of previously reported inter-laboratory values (Hathorne et al., 2013). Results of total REE concentrations are summarised in Supp. Tbl. 3 and provided in Data Table 1). Total REE concentrations in the four cores ranged from 10.4 ppb (SUD 12.1) to 247.74 ppb (FRI 12.1; Fig. 2; Supp. Tbl. 3). Sample relative standard deviations (RSD) over four measurements were $<5 \%$ for all elements except for Sm $(8.26 \%$; Supp. Tbl. $\Sigma 4$ ). Cerium anomalies (Ce/Ce*; Fig. 2c) and Europium anomalies (Eu/ Eu*; Supp. Fig. 2) ranged from 0.4 to 3.8 and 0.6 to 4.3 , respectively (Supp. Tbl. 3). All corals displayed LREE depletion $\left(\mathrm{Nd}_{\mathrm{SN}} / \mathrm{Yb}_{\mathrm{SN}}\right.$; $\left.0.2-0.8\right)$ relative to HREE (Figs. 2e and 3) and super-chondritic $\mathrm{Y} / \mathrm{Ho}$ values (70-384; Fig. 2a and b; Supp. Tbl. 3). $\Sigma$ REE, Y/Ho and Ba/Ca time series data collectively covered the time period 1999-2006 (Fig. 4), but showed poorly defined relationships between $\mathrm{Ba} / \mathrm{Ca}$ and REE proxies. Although we present REE data as $\mathrm{REE}$ concentration for ease of comparison with previously published seawater and coral records (Jupiter, 2008; Wyndham et al., 2004), comparison of time-series patterns between $\Sigma$ REE and REE/Ca (as reported in Saha et al., 2019) did not change the interpretation of the data presented here. Peaks in scaled IREE concentrations in corals HI 12.1, FRI 12.3 and SUD 12.1 broadly trace local rainfall variability, but sub-annual alignment is relatively poor (Fig. 5).

\subsection{Variance of geochemical concentrations}

Statistical results are provided in detail in Supp. Table 5. In summary, for the overlapping period 2001-2002 $\mathrm{Y} / \mathrm{Ho}, \mathrm{Nd}_{\mathrm{SN}} / \mathrm{Yb}_{\mathrm{SN}}$ and $\mathrm{Ba} / \mathrm{Ca}$ indicate a significant difference between the four cores $(\mathrm{F}=$, 504.9,98.27 and 17.09 respectively; $p=<0.001$ ). Levene's tests for homogeneity of variance from means were $<p=0.05$ for all ANOVA's (Supp. Tbl. 5). Kruskal-Wallis test of $\Sigma$ REE showed a significant difference between the cores $(p=<0.05)$ and Mann-Whitney post hoc tests (95\% confidence interval) revealed that for the overlapping period of 2001-2002, average $\Sigma$ REE concentrations were all significantly different from each other ( $p=<0.05$ ). Summary statistics for 2001-2002 demonstrate that the maximum $\Sigma$ REE concentrations in coral FRI 12.1 are $>1.5$ and 3.5 times higher than HI 12.1 and FRI 12.3, respectively, whilst the mid-shelf coral (SUD 12.1) contained between 2 --8 times lower concentrations of $\Sigma$ REE than the inshore corals.

Mid-shelf coral (SUD 12.1) Y/Ho ratio was significantly higher than that of the inshore cores, but no significant difference in $\mathrm{Y} / \mathrm{Ho}$ was found between cores FRI 12.1, FRI 12.3 and HI 12.1. Light REE depletion $\left(\mathrm{Nd}_{\mathrm{SN}} / \mathrm{Yb}_{\mathrm{SN}}\right)$ was significantly higher in core FRI 12.1 compared with all other cores, and in core FRI 12.3 compared to SUD 12.1. Average $\mathrm{Ba} / \mathrm{Ca}$ in core $\mathrm{HI} 12.1$ was significantly higher than all other cores, yet there was no statistical difference between Ba/Ca in cores FRI 12.1, FRI 12.3 and SUD 12.1 (Supp. Tbl. 5).

\section{Discussion}

The use of both luminescence bands (Lough, 2011a, 2011b; Rodriguez-Ramirez et al., 2014) and geochemical proxies (see Lewis et al., 2018; Saha et al., 2016 and references therein) in corals to extend environmental and climatic records beyond modern instrumentation is 


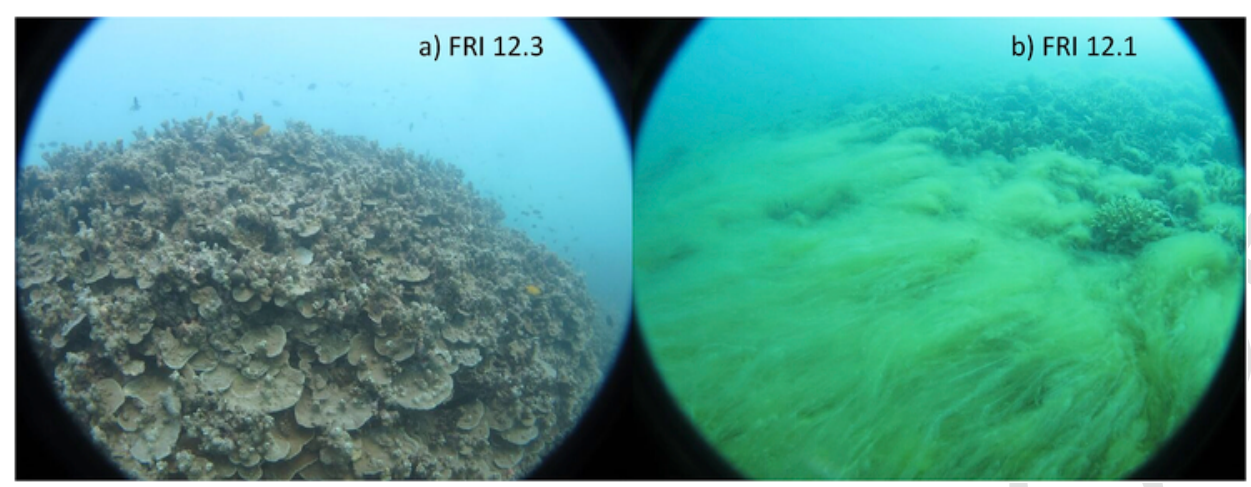

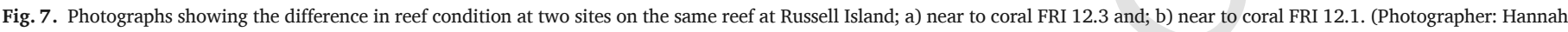
Markham).
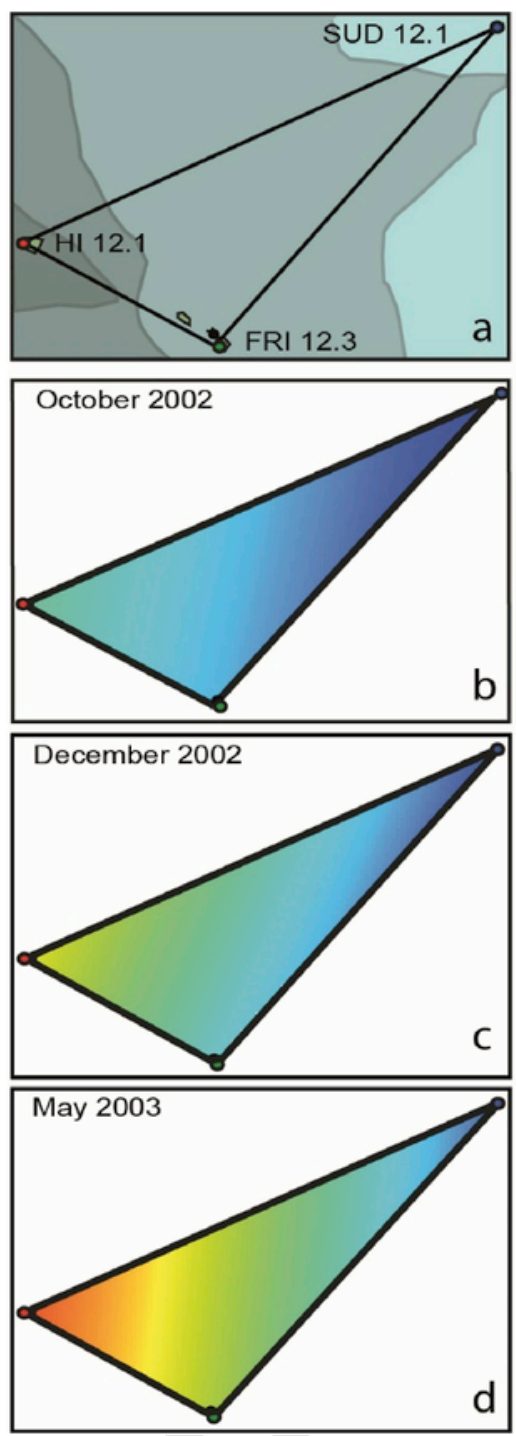

Fig. 8. Comparison of gridded spatial interpolation (kriging) model of average total rare earth element ( $\Sigma$ REE-ppb) concentrations derived from three Porites spp. coral cores with reconstructed flood plume dynamics in the Wet Tropics, Great Barrier Reef, Australia; a) Cropped area of interest (triangle) and expected water quality gradient derived from satellite observations (Devlin et al., 2001); b) Low rainfall; c) moderate rainfall and d) high rainfall (see arrows Fig. 4). becoming common-place. However, heterogeneity in geochemical signals among corals of the same genus within close proximity to each other, and decoupling of geochemical signals from both river discharge data and luminescent bands is common (Lewis et al., 2012, 2018; McCulloch et al., 2003; Saha et al., 2018b; Sinclair, 2005). Until the underlying causes of the differences in elemental behaviour are fully understood, and alternative proxies developed, the use of geochemical signals for robust high-resolution palaeoenvironmental reconstruction is limited. Here we assess sub-annual REY geochemistry in four Porites spp. coral cores from the Wet Tropics, GBR, against instrumental river discharge and rainfall data, as well as cross shelf water quality gradients.

\subsection{Rare earth elements}

Average aqueous $\Sigma$ REE concentrations around the Frankland Islands would be expected to reflect the known flood plume gradient from High Island to Sudbury Cay (Fig. 1; HI $12.1>$ FRI $12.1>$ FRI $12.3>$ SUD 12.1) and respond to discharge events from the Russell-Mulgrave River. Combined coral core time series spanned $1999-2006$, with an overlap between the four cores in 2001-2002 (Fig. 4). $\Sigma$ REE concentrations were generally comparable to previously reported coral values from the GBR given both the spatial and temporal variability of REEs in seawater (Supp. Tbl. 4; Jupiter, 2008; McCulloch et al., 2003; Saha et al., 2019; Sinclair and McCulloch, 2004; Wyndham et al., 2004). The average $\Sigma$ REE concentration for FRI 12.3 (55 ppb) is similar to previously reported values from Round Top Island [53 ppb, $5 \mathrm{~km}$ offshore (Jupiter, 2008)]; however, both FRI 12.1 ( $\sim 10 \mathrm{~km}$ offshore) and HI 12.1 ( $\sim 6 \mathrm{~km}$ offshore) have significantly higher average $\Sigma$ REE concentration values (112 ppb and $85 \mathrm{ppb}$, respectively). Average $\Sigma$ REE values for SUD 12.1 $(17 \mathrm{ppb})$ are only moderately lower than those reported for a similar mid-shelf site at Keswick Island [ 25ppb (Jupiter, 2008);]. This suggests that the $\Sigma$ REE concentration in corals are reliably recording broad scale cross-shelf water quality.

Overall, in the Frankland Islands, average inshore $\Sigma$ REE concentrations were 2.5-7.5x higher at inshore locations than at the mid-shelf (Fig. 2; Supp. Tbl. 3). High Island, which experiences more frequent flood plumes (Devlin et al., 2001, 2002) and greater turbidity (Fabricius et al., 2013), displayed higher average concentrations of $\Sigma$ REE than FRI 12.3 and SUD 12.1 across the time series ( $85>55>17 \mathrm{ppb}$, respectively), however, the coral with the highest average $\Sigma$ REE concentration and variability was from the NW side of Russell Island (112 ppb; FRI 12.1; Figs. 1 and 2), with two peaks of $\sim 250 \mathrm{ppb}$ occurring in the Austral autumn-winter dry period (Fig. 4c). $\mathrm{REY}_{\mathrm{SN}}$ patterns for FRI 12.1 show highly variable depletion of LREEs $\left(\mathrm{Nd}_{\mathrm{SN}} / \mathrm{Yb}_{\mathrm{SN}}=0.18-0.75\right.$; Fig. 2e) and a generally reduced negative Ce anomaly similar to patterns observed in corals from Vietnam following port dredging activities (Nguyen et al., 2013). Increased $\mathrm{Nd}_{\mathrm{SN}} / \mathrm{Yb}_{\mathrm{SN}}$ ra- 
tios (i.e., decreased LREE depletion; Fig. 2e) and higher Zr concentrations (Fig. 2f) suggest that resuspension of sediment may be the primary driver of the unexpected peaks in this coral. The location of this coral at an inter-reef passage (diurnal tidal range $\sim 2.5 \mathrm{~m}$ ), and close to a permanent mooring buoy, may contribute to resuspension of sediments through the channel. The larger tissue thickness of this colony compared to the other cores from the region $(0.9 \mathrm{~cm}$ compared to $\sim 0.5 \mathrm{~cm}$; Supp. Tbl. 1) also supports the notion that this coral may have increased exposure to both organic and inorganic nutrient sources (Barnes and Lough, 1992). However, monthly resolution sampling of this core for $\sim 1950$ showed lower $\Sigma$ REE concentrations (53-80 ppb) compared to the 1999-2002 period (78-248 ppb), possibly indicating increased sediment exposure at this site following coastal development (Supp. Tbl. 3).

Average $\Sigma$ REE concentrations in the remaining three cores were as expected, with High Island coral concentration as much as $1.5 \mathrm{x}$ higher than those observed co-occurring in FRI 12.3 (132 ppb versus $85 \mathrm{ppb}$, respectively) and four times higher than the mid-shelf coral SUD 12.1 (32 ppb). Average $\mathrm{Nd}_{\mathrm{SN}} / \mathrm{Yb}_{\mathrm{SN}}$ ratios for the High Island coral, however, demonstrate higher depletion of LREEs relative to other inshore sites (HI $12.1=0.2<$ FRI $12.3=0.26<$ FRI $12.1=0.33$; Fig. $4 \mathrm{e}$ ). The overall higher $\Sigma$ REE concentration but greater LREE depletion in coral HI 12.1 may indicate that the water quality at this site is influenced both by particulate and dissolved fractions that are relatively persistent throughout the year.

Y/Ho ratios for the inshore corals (minimum 69-74; maximum 108-125) fall close to that of near surface marine values ( 40-140; Alibo and Nozaki, 1999; Nozaki et al., 1997; Zhang and Nozaki, 1996; Zhang and Nozaki, 1998), and are similar to previous coral records from the inshore GBR (67; Jupiter, 2008) and coastal Vietnam (52-112; Nguyen et al., 2013); however, significantly higher $\mathrm{Y} / \mathrm{Ho}$ ratios were observed at Sudbury Cay ( $>300$; Fig. 2a and b). High Y/Ho ratios (140) also have been observed by Jupiter et al. (2008) at a GBR mid-shelf site, and calculated ratios from Heron Reef corals (southern GBR) range from 300 to 1200 (Webb and Kamber, 2000), although the data are near detection limits, which can affect ratios significantly. The more robust $\mathrm{Y} /$ Ho ratios of the associated reefal microbialites at Heron Island had mean Y/Ho values of 56.17 (Webb and Kamber, 2000). Superchondritic ratios are driven by extremely low Ho values recorded in the corals at both Sudbury Cay and Heron Reef ( $0.3 \mathrm{ppb}$ ) relative to Y ( $89 \mathrm{ppb})$, supporting previous observations of the persistence of $\mathrm{Y}$ in the soluble phase of sea water (Nozaki et al., 1997; Zhang and Nozaki, 1998). Yttrium desorbed from particulate sediment in the estuarine mixing zone effectively traces the extent of discharge plumes due to the strong solution complexation of Y (and to a lesser extent HREEs) with carbonate ions (dissolved fraction) compared with LREE covalent complexation to particulates in sea water (Quinn et al., 2004; Zhang and Nozaki, 1996). Although beyond the scope of this study, future work is recommended to determine the discrepancies between seawater Y/Ho ratios and mid-shelf corals.

\subsection{Oceanic processes affecting geochemical signals}

Average $\mathrm{REY}_{\mathrm{SN}}$ patterns in the Frankland Island coral cores largely reflect results expected for coastal sea water, with a progressive enrichment of HREE relative to LREE and distinctive negative Ce anomalies (Fig. 3). Average $\mathrm{REY}_{\mathrm{SN}}$ values for corals FRI 12.3 and HI 12.1 are indistinguishable from results previously reported by Wyndham et al. (2004) for the same region (Fig. 3). Some exceptions to the overall trend in sea water REE distributions were periods of positive Ce anomalies in corals FRI 12.1, FRI 12.3 and SUD 12.1 (Figs. 2c and 3) indicating increased terrestrial influence. Whilst positive Ce anomalies co-occur with higher $\Sigma$ REE concentrations at the inshore locations, positive Ce anomalies are unexpectedly associated with low $\Sigma$ REE concen- trations in the mid-shelf coral (SUD 12.1; Fig. 4c). Average REY $\mathrm{SN}_{\text {pat- }}$ terns at Sudbury Cay (SUD 12.1) are characterised by lower overall REY values, very high $\mathrm{Y} / \mathrm{Ho}$ ratios and positive Eu anomalies. Positive Eu anomalies have been previously attributed to shallow, well oxygenated waters in corals from Isla de Sacrificios Reef, Mexico (Kasper-Zubillaga et al., 2010), and with weathered feldspars associated with volcanic bedrock in Vanuatu (Cabioch et al., 2006). However, at Sudbury Cay the mid-shelf Eu anomaly may represent intrusive upwelling of older Pacific water (Grenier et al., 2013). The positive Eu anomalies at the mid-shelf site occur concomitantly with the broad Spring-Summer peaks of $\mathrm{Ba} / \mathrm{Ca}$, an association not found in any of the inshore corals (Supp. Fig. 2). Well preserved positive Eu anomalies also have been reported in seawater values obtained from the Coral Sea and Pacific Ocean (Grenier et al., 2013) and may be the source of the Eu anomalies identified at Sudbury Cay. In the Frankland Islands region of the Queensland continental shelf, the outer shelf reef structure allows cross shelf transfer of water masses from the Coral Sea and subsurface intrusive upwelling can occur 50-70 km from the shelf edge (Benthuysen et al., 2016; Furnas et al., 2011), which is within the range of Sudbury Cay. Unfortunately, $\mathrm{Eu}$ values from other mid-shelf or shelf edge corals that may be under the influence of upwelling are currently unavailable for comparison but provide a focus for future work.

Winter baseline $\mathrm{Ba} / \mathrm{Ca}$ values in all cores were $\sim 2-3 \mu \mathrm{molmol}^{-1}$, similar to surface seawater baseline levels reported elsewhere on the GBR of between 2.8 and $3.8 \mu \mathrm{molmol}^{-1}$ (Walther et al., 2013), although slightly lower than values reported for most corals (Lewis et al., 2012; McCulloch et al., 2003; Saha et al., 2018a; Walther et al., 2013). The peak in Austral spring-summer Ba/Ca in the mid-shelf coral (SUD 12.1), not related to any discharge event, was $4.58 \mathrm{molmol}^{-1}$, which is higher than values for FRI 12.1 and FRI 12.3, and similar to HI 12.1 for the same time (4.69 $\mathrm{molmol}^{-1}$ ). Broad Ba/Ca peaks in Austral spring-summer in the mid-shelf and shelf edge region of the GBR also were noted by Alibert et al. (2003) and Walther et al. (2013). At Myrmidon reef, close to the shelf edge, upwelling was suggested as the primary source of nutrient- (and Ba-) rich waters (Walther et al., 2013), which is the most likely source at Sudbury Cay.

\subsection{Quality of terrestrial runoff proxies}

While scaled sub-annual time series of $\Sigma$ REEs in cores FRI 12.3, HI 12.1 and SUD 12.1 co-vary and are broadly aligned with rainfall (Fig. 5) and river discharge (Fig. 4d), temporal variability not representing river discharge or rainfall is apparent at sub-annual scales (Fig. 4). Ba/Ca were highly variable within the cores at sub-annular to annular scales, but co-varied in cores FRI 12.3 and HI 12.1 (Fig. 4a and b). On the mid-shelf (SUD 12.1), $\Sigma$ REE and Y/Ho co-varied throughout the time series; however, $\mathrm{Ba} / \mathrm{Ca}$ peaks and troughs did not align with $\Sigma \mathrm{REE}, \mathrm{Y} / \mathrm{Ho}$ or the geochemical signals from the other cores (Fig. 4d). These results support previous findings that at sub-annual timescales geochemical signals in corals, especially $\mathrm{Ba} / \mathrm{Ca}$, do not always represent terrigenous influence and are affected by both biological and broad scale oceanographic processes.

The clearest $\Sigma$ REE signal (i.e., well defined peaks and troughs) was obtained from core FRI 12.3 which, although inshore, is located slightly south of the predominant plume direction and is therefore less affected by minor river discharge events (Fig. 1; Devlin et al., 2001). The more defined geochemical signal in coral FRI 12.3 is also likely due to the comparatively low tissue thickness/extension ratio in this coral compared to the other colonies (Supp. Tbl. 1). Generally, increases in $\Sigma$ REE concentrations in the Frankland Islands appear to precede maximum discharge events (Fig. 4). This may be due to the time-averaging effect of geochemical incorporation throughout the depth of the living tissue layer. Alternatively, initial increases in $\mathrm{REE}$ concentrations in the corals may record greater sediment flux derived from 
the earliest seasonal rainfall events and not just those associated with high river discharge (Saha et al., 2018a). The scaled LREE signals for FRI 12.3, HI 12.1 and SUD 12.1 and rainfall data (Fig. 4) indicates the latter is the most likely scenario, suggesting that even when discharge events are moderate, substantial sediment delivery still occurs to these reefs. The seasonally earlier and smaller discharge events may represent initial increased erosion following dryer months when mobilisation of fine topsoil is more prevalent. Therefore, at sub-annual time scales $\Sigma$ REEs incorporated into inshore corals may offer greater potential for use in local rainfall reconstruction than for quantifying sediment loads associated with river discharge volume. The timing of stochastic events, such as droughts and cyclones, and seasonal fluctuations in rainfall and groundcover, may independently mediate the sediment loads transported by a given discharge and therefore REE concentrations (Saha et al., 2018a, 2019). Importantly, in the Frankland Islands, shale normalised REY distributions were found to provide a specific fingerprint for the effects of terrigenous sediment discharge on the water quality where the corals grew, thus supporting the results of Saha et al. (2019). Although both studies found complex behaviour of Ce, variations in LREE depletion (as measured by $\mathrm{Nd}_{\mathrm{SN}} / \mathrm{Yb}_{\mathrm{SN}}$ ), and $\mathrm{Y} / \mathrm{Ho}$ ratios reflect the mixing of open seawater and varying degrees of terrigenous 'mud', with the mid-shelf Sudbury coral showing the cleanest seawater patterns as expected.

Annual time series of $\mathrm{Ba} / \mathrm{Ca}$ and $\mathrm{Y} / \mathrm{Ho}$ co-varied with $\Sigma \mathrm{REE}$ in cores HI 12.1 and FRI 12.3, however sub-annual alignment was poor among all cores (Fig. 4). A lack of correlation in sub-annual $\mathrm{Ba} / \mathrm{Ca}$ and $\mathrm{Y}$ time-series signals among inshore Porites also have been reported in the Whitsunday Islands (Lewis et al., 2012), with Ba/Ca peaks commonly decoupled from discharge (Lewis et al., 2012; Sinclair, 2005). Notably, the most reliable relationships previously reported for $\mathrm{Ba} / \mathrm{Ca}$ and river discharge were obtained from corals under the influence of the Burdekin River in the Dry Tropics, a region defined by prolonged periods of drought followed by large rainfall and discharge events (Alibert et al., 2003; McCulloch et al., 2003; Sinclair, 2005). Satellite image observations of flood events have shown that in the Burdekin catchment, where cattle grazing is dominant, plumes contain higher levels of inorganic sediments compared to catchments in which sugarcane is grown, such as is the case for the Frankland Islands where dissolved and particulate organics are generally higher (Schroeder et al., 2012). The desorption of Ba from large quantities of inorganic fine clays in the mixing zone of the Burdekin River would therefore behave more conservatively as a dissolved tracer of flood plume dynamics across the shelf and onto adjacent reefs (McCulloch et al., 2003) than in regions where organics dominate plume composition. Barium concentrations in coastal waters, therefore, appear to be not only biologically mediated, but also largely dependent on regional scale hydrology (e.g. Dry Tropics versus Wet Tropics; Devlin et al., 2012), catchment geology and land use.

\subsection{Water quality gradient reconstruction}

Spatial interpolations were applied to average "dry-period" (2001-2002) $\Sigma \mathrm{REE}, \mathrm{Y} / \mathrm{Ho} \mathrm{Nd}_{\mathrm{SN}} / \mathrm{Yb}_{\mathrm{SN}}$ and $\mathrm{Ba} / \mathrm{Ca}$ values to assess whether both broad scale and local spatial patterns of water quality could be reliably reconstructed from coral cores. The spatial interpolation model of $\mathrm{Y} / \mathrm{Ho}$ produced a simple water quality gradient (Fig. 6a) with inshore $\mathrm{Y} / \mathrm{Ho}$ ratios not differentiating well at local scales but predicting well the expected inshore-offshore gradient. Therefore, spatial interpolation of $\mathrm{Y} / \mathrm{Ho}$ offers potential for reconstructing palaeo-water quality gradients in regions where local hydrodynamics are not complex, or where palaeo-cross shelf water quality gradients are required for ecological evaluation.

Compared to patterns of turbidity derived from in situ data (Fabricius et al., 2013) and flood plume frequency analysis (Fig. 1;
Devlin et al., 2002; Devlin et al., 2001), the $\Sigma$ REE spatial interpolation model underestimated turbidity at High Island relative to NW Russell Island (FRI 12.1; Fig. 6b). The higher $\Sigma$ REE concentrations in core FRI 12.1 than $\mathrm{HI} 12.1$ was unexpected, as nearby in situ monitoring of these Islands for the period 2007-2010 indicates higher mean and maximum turbidity at High Island (0.95 and $\sim 7$ Nephelometric Turbidity Units [NTU] respectively) compared with Russell Island (0.65 and 2 NTU; Fabricius et al., 2013; Schaffelke et al., 2008). Flood plume frequency mapping of Russell-Mulgrave River discharge events also indicates that High Island experiences more frequent flood plumes than Russell Island (Devlin et al., 2001, 2002). As the in situ data logger for the 2007-2010 monitoring period was located closer to FRI $12.3(\sim 80 \mathrm{~m})$ than to FRI $12.1(\sim 350 \mathrm{~m})$, the difference in $\Sigma$ REE concentrations may be due to sub-reef scale differences in turbidity or to different turbidity distribution between 2007 and 2010 than in 2000-2001. A mean monthly record of turbidity obtained in 2000 (Macdonald et al., 2013) indicated a higher NTU value (1.3 NTU) for the NW of Russell Island than values observed at two sites on the SW of High Island reef (0.8-1.2 NTU) for the same period, supporting our interpretation of localised resuspension at this site. Although FRI 12.1 and FRI 12.3 cores are separated by only $\sim 500 \mathrm{~m}$ (Fig. 1) the reef condition at each site was substantially different, with the reef near FRI 12.3 healthy with high coral cover (Fig. 7a), whereas nearer to FRI 12.1 corals were degraded and largely covered by macroalgae (Fig. 7b). Whilst the $\Sigma$ REE spatial interpolation shows potential as an effective tool for reconstructing complex palaeo-water quality gradients, these results highlight the importance of understanding the influence of local reef hydrodynamics on water quality and reef condition.

Spatial interpolation of LREE depletion $\left(\mathrm{Nd}_{\mathrm{SN}} / \mathrm{Yb}_{\mathrm{SN}}\right)$ and $\mathrm{Ba} / \mathrm{Ca}$ did not effectively reconstruct the known cross shelf water quality gradient (Fig. $6 \mathrm{c}$ and d). Whilst the inshore corals $\mathrm{Ba} / \mathrm{Ca}$ reflected the known water quality gradient, the higher $\mathrm{Ba} / \mathrm{Ca}$ values in the mid-shelf coral (SUD 12.1) skewed the model, likely reflecting the introduction of upwelled $\mathrm{Ba}$ at that site. Hence, with only a single mid-shelf locality, a two-source Ba model could easily cause the gradient to appear to be at a high angle to the sources of the Ba (i.e., perpendicular to the coast). Conversely, LREE depletion was lower at Russell Island (FRI 12.1 and 12.3) compared to High Island (HI 12.1), suggesting more terrigenous influence south of the predominant plume direction (Fig. 6c), again consistent with additional sediment suspension at FRI 12.1.

Given that $\Sigma$ REE spatial modelling best represented the measured local/regional water quality, the progression of a water quality gradient from a low discharge (October 2002) to high discharge (May 2003) event was tested for the region (Figs. 3 and 8; excluding core FRI 12.1). This model provides evidence of cross-shelf development of a water quality gradient following cumulative discharge events from the Russell-Mulgrave catchments, signifying the potential for corals to record discharge across the continental shelf. Whilst longer geochemical records are planned for future work, the data presented here provide a basis for guiding further evaluation and validation for the use of REEs and $\mathrm{Y}$ as tracers of terrigenous sediment-affected water quality on coral reefs.

\section{Conclusions}

The extensive coral reefs of the Great Barrier Reef (GBR) grow in a diverse range of environments, with inshore reefs subjected to substantially higher terrigenoclastic input from rivers as well as resuspension of coastal sediment compared to mid- and outer-shelf reefs (Brodie et al., 2012; Lewis et al., 2012; Perry et al., 2013). The unique behaviours of REEs and Y in coastal mixing zones suggest potential use for reconstructing palaeo-climatic and environmental conditions that have controlled reef growth. Although further work is required to fully understand both the temporal and spatial variability of REYs, this study 
demonstrates that geochemical proxies derived from corals can be used successfully to interpret and track spatial gradients in REY systematics in coastal seawater.

The primary aim of this study was to identify potential uses for REY geochemistry in coastal locations for use in palaeo-research. From our results we can conclude:

1. RREE concentration may be a better indicator of regional rainfall than river discharge, as early season (smaller) peaks are likely associated with more efficient removal of top soils following dry periods.

2. Scaled $\Sigma$ REE time series data was cohesive in 3 of the 4 coral cores (HI 12.1, FRI 12.3 and SUD 12.1) at annual to sub-annual scales regardless of significant differences in total $\Sigma$ REE concentrations between sites, thus offering potential for water quality reconstructions, although further refinement is required

3. $\Sigma$ REE concentrations have the potential to track changes in sediment delivery to the GBR since European settlement, with higher $\Sigma$ REE observed in 1999-2002 (78-250 ppb in dry and wet years) than in 1950 (53-79 ppb).

4. Spatial interpolation models of $\mathrm{Y} / \mathrm{Ho}$ serve as an indicator for broad scale cross-shelf water quality; however, $\Sigma$ REE models better predict known turbidity and flood plume patterns in regions of more complex oceanography. Applying a similar approach to longer Porites cores, or from corals obtained from reef matrix cores would allow for interpretation of ecological data in the context of relative turbidity among sites through time.

5. $\mathrm{Ba} / \mathrm{Ca}$ in the Wet Tropics region did not represent the known water quality gradient due to higher than expected values from the mid-shelf coral (SUD 12.1), likely due to delivery of nutrient rich waters via subsurface intrusive upwelling in the Austral Spring-Summer. Eu anomalies also may have the potential to identify upwelling events on the GBR.

\section{Acknowledgments}

We would like to thank two reviewers for comments which improved this manuscript. We would also like to thank Hannah Markham, Martina Prazeres, Juan Pablo D'Olivo, Entao Liu, Mauro Lepore, Alberto Rodrigues-Ramirez, Ian Butler, Emma Lewis, Marine, Vincenzo and the crew of the MV Coral Emperor for assistance in the field. This project was funded under NERP Tropical Ecosystems Hub Project 1.3 — Characterising the cumulative impacts of global, regional and local stressors on the present and past biodiversity of the GBR to J-x. Zhao, J.M. Pandolfi, G. Roff, Y-x. Feng, T. Done and T. Clark, ARC Discovery Project DP180102526 to J-x. Zhao and others, and an Australian Postgraduate Award to NDL. Samples were collected under permit under permit G12/ 34,979.1.

\section{Appendix A. Supplementary data}

Supplementary data to this article can be found online at https:// doi.org/10.1016/j.marpolbul.2019.110634.

\section{References}

Aizawa, S., 2008. Determination of trace elements in carbonate reference samples by instrumental neutron activation analysis. J. Radioanal. Nucl. Chem. 278 (2), 349-352.

Akagi, T., Hashimoto, Y., Fu, F.-f., Tsuno, H., Tao, H., Nakano, Y., 2004. Variation of the distribution coefficients of rare earth elements in modern coral-lattices: species and site dependencies 11 Associate editor: R. H. Bryne. Geochem. Cosmochim. Acta 68 (10), 2265-2273.

Alibert, C., Kinsley, L., Fallon, S.J., McCulloch, M.T., Berkelmans, R., McAllister, F., 2003. Source of trace element variability in Great Barrier Reef corals affected by the Burdekin flood plumes. Geochem. Cosmochim. Acta 67 (2), 231-246.

Alibo, D.S., Nozaki, Y., 1999. Rare earth elements in seawater: particle association, shale-normalization, and Ce oxidation. Geochem. Cosmochim. Acta 63 (3), 363-372.
Arthington, A.H., Connolly, N.M., Pearson, R.G., 2007. Introduction: the catchment to ree program and stream ecosystem health monitoring. In: Arthington, A.H., Pearson, R.G. (Eds.), Biological Indicators of Ecosystem Health in Wet Tropics Stream. Final Report Task 3 Catchment to Reef Research Program. CRC for Rainforest Ecology and Management and CRC for the Great Barrier Reef World Heritage Area. James Cook University, Townsville, pp. 1-13.

Barnes, D.J., Lough, J.M., 1992. Systematic variations in the depth of skeleton occupied by coral tissue in massive colonies of Porites from the Great Barrier Reef. J. Exp. Mar. Biol. Ecol. 159 (1), 113-128.

Benthuysen, J.A., Tonin, H., Brinkman, R., Herzfeld, M., Steinberg, C., 2016. Intrusive upwelling in the central great barrier reef. J. Geophys. Res.: Oceans 121 (11), 8395-8416.

Brodie, J., Wolanski, E., Lewis, S., Bainbridge, Z., 2012. An assessment of residence times of land-sourced contaminants in the Great Barrier Reef lagoon and the implications for management and reef recovery. Mar. Pollut. Bull. 65 (4-9), 267-279.

Cabioch, G., Camoin, G., Webb, G.E., Le Cornec, F., Garcia Molina, M., Pierre, C., Joachimski, M.M., 2006. Contribution of microbialites to the development of coral reefs during the last deglacial period: case study from Vanuatu (South-West Pacific). Sediment. Geol. 185 (3), 297-318.

Connolly, N.M., Pearson, B., Loong, D., Maughan, M., Pearson, R.G., 2007. Hydrology, geomorphology and water quality of four wet Tropics streams with contrasting land-use management. In: Arthington, A.H., Pearson, R.g. (Eds.), Biological Indicators of Ecosystem Health in Wet Tropics Streams. Final Report Task 3 Catchment to Reef Research Program Cooperative Research Centre for Rainforest Ecology and Management and Cooperative Research Centre for the Great Barrier Reef World Heritage Area. pp. 15-78.

De'ath, G., Fabricius, K., 2010. Water quality as a regional driver of coral biodiversity and macroalgae on the Great Barrier Reef. Ecol. Appl. 20 (3), 840-850.

De'ath, G., Fabricius, K.E., Sweatman, H., Puotinen, M., 2012. The 27-year decline of coral cover on the Great Barrier Reef and its causes. Proc. Natl. Acad. Sci. U. S. A 109 (44), 17995-17999.

DeCarlo, T.M., Cohen, A.L., 2017. Dissepiments, density bands and signatures of thermal stress in Porites skeletons. Coral Reefs 36 (3), 749-761.

Devlin, M., Waterhouse, J., Brodie, J., 2002. Terrestrial discharge into the Great Barrier Reef: distribution of riverwaters and pollutant concentrations during flood plumes. Proc. Ninth Int. Coral Reef Symp. Bali 23-27, 1205-1211, October 2000.

Devlin, M., Waterhouse, J., Taylor, J., Brodie, J., 2001. Flood Plumes in the Great Barrier Reef: Spatial and Temporal Patterns in Composition and Distribution, vol. 68, Research Publication No.

Devlin, M.J., McKinna, L.W., Álvarez-Romero, J.G., Petus, C., Abott, B., Harkness, P., Brodie, J., 2012. Mapping the pollutants in surface riverine flood plume waters in the Great Barrier Reef, Australia. Mar. Pollut. Bull. 65 (4-9), 224-235.

Dubinin, A.V., 2004. Geochemistry of rare earth elements in the ocean. Lithol. Miner. Resour. 39 (4), 289-289.

Elderfield, H., Upstill-Goddard, R., Sholkovitz, E.R., 1990. The rare earth elements in rivers, estuaries, and coastal seas and their significance to the composition of ocean waters. Geochem. Cosmochim. Acta 54 (4), 971-991.

Elliot, M., Welsh, K., Chilcott, C., McCulloch, M., Chappell, J., Ayling, B., 2009. Profiles of trace elements and stable isotopes derived from giant long-lived Tridacna gigas bivalves: potential applications in paleoclimate studies. Palaeogeogr. Palaeoclimatol. Palaeoecol. 280 (1), 132-142.

Fabricius, K.E., De'ath, G., Humphrey, C., Zagorskis, I., Schaffelke, B., 2013. Intra-annual variation in turbidity in response to terrestrial runoff on near-shore coral reefs of the Great Barrier Reef. Estuarine. Coast Shelf Sci. 116, 57-65.

Fallon, S.J., McCulloch, M.T., 2002. Porites corals as recorders of mining and environmental impacts: misima Island, Papua New Guinea. Geochem. Cosmochim. Acta 66 (1) $45-62$

Furnas, M., 2003. Catchments and Corals: Terrestrial Runoff to the Great Barrier Reef. Australian Institute of Marine Science and CRC Reef Research Centre, Townsville, Qld.

Furnas, M., Alongi, D., McKinnon, D., Trott, L., Skuza, M., 2011. Regional-scale nitrogen and phosphorus budgets for the northern $\left(14^{\circ} \mathrm{S}\right)$ and central $\left(17^{\circ} \mathrm{S}\right)$ Great Barrier Ree shelf ecosystem. Cont. Shelf Res. 31 (19), 1967-1990.

Grenier, M., Jeandel, C., Lacan, F., Vance, D., Venchiarutti, C., Cros, A., Cravatte, S., 2013. From the subtropics to the central equatorial Pacific Ocean: Neodymium isotopic composition and rare earth element concentration variations. J. Geophys. Res.: Oceans 118 (2), 592-618.

Hammer, , Harper, D.A.T., Ryan, P.D., 2001. Past: paleontological statistics software package for education and data analysis. Palaeontol. Electron. 4 (1), XIX-XX.

Hathorne, E.C., Gagnon, A., Felis, T., Adkins, J., Asami, R., Boer, W., Caillon, N., Case, D., Cobb, K.M., Douville, E., deMenocal, P., Eisenhauer, A., Garbe-Schönberg, D., Geibert, W., Goldstein, S., Hughen, K., Inoue, M., Kawahata, H., Kölling, M., Cornec, F.L., Linsley, B.K., McGregor, H.V., Montagna, P., Nurhati, I.S., Quinn, T.M., Raddatz, J., Rebaubier, H., Robinson, L., Sadekov, A., Sherrell, R., Sinclair, D., Tudhope, A.W., Wei, G., Wong, H., Wu, H.C., You, C.-F., 2013. Interlaboratory study for coral Sr/ $\mathrm{Ca}$ and other element/Ca ratio measurements. Geochem. Geophys. Geosyst. 14 (9), $3730-3750$.

Hendy, E.J., Gagan, M.K., Lough, J., 2003. Chronological control of coral records using luminescent lines and evidence for non-stationary ENSO teleconnections in northeast Australia. Holocene 13 (2), 187-199.

Hopley, D., 1982. The Geomorphology of the Great Barrier Reef: Quaternary Development of Coral Reefs. Wiley, New York. 
Hoyle, J., Elderfield, H., Gledhill, A., Greaves, M., 1984. The behaviour of the rare earth elements during mixing of river and sea waters. Geochem. Cosmochim. Acta 48 (1), $143-149$.

Hughes, T.P., Day, J.C., Brodie, J., 2015. Securing the future of the great barrier reef. Nat. Clim. Chang. 5 (6), 508-511.

Isdale, P., 1984. Fluorescent bands in massive corals record centuries of coastal rainfall. Nature 310 (5978), 578-579.

Isdale, P.J., Stewart, B.J., Tickle, K.S., Lough, J.M., 1998. Palaeohydrological variation in a tropical river catchment: a reconstruction using fluorescent bands in corals of the Great Barrier Reef, Australia. Holocene 8 (1), 1-8.

Jupiter, S., 2008. Coral rare earth element tracers of terrestrial exposure in nearshore corals of the Great Barrier Reef. In: Proceedings of the 11th International Coral Reef Symposium, (Ft. Lauderdale, Florida).

Jupiter, S., Roff, G., Marion, G., Henderson, M., Schrameyer, V., McCulloch, M., Hoegh-Guldberg, O., 2008. Linkages between coral assemblages and coral proxies of terrestrial exposure along a cross-shelf gradient on the southern Great Barrier Reef. Coral Reefs 27 (4), 887-903.

Kamber, B.S., Greig, A., Collerson, K.D., 2005. A new estimate for the composition of weathered young upper continental crust from alluvial sediments, Queensland, Australia. Geochem. Cosmochim. Acta 69 (4), 1041-1058.

Kasper-Zubillaga, J.J., Rosales-Hoz, L., Bernal, J.P., 2010. Rare earth elements in corals from the Isla de Sacrificios reef, Veracruz, Mexico. Chemie der Erde - Geochemistry Interdisci. J. Chem. Probl. Geosci. Geoecol. 70 (1), 55-60.

Lawrence, M.G., Greig, A., Collerson, K.D., Kamber, B.S., 2006a. Rare earth element and yttrium variability in South East Queensland waterways. Aquat. Geochem. 12 (1), 39-72.

Lawrence, M.G., Jupiter, S.D., Kamber, B.S., 2006b. Aquatic geochemistry of the rare earth elements and yttrium in the Pioneer River catchment, Australia. Mar. Freshw. Res. 57 (7), 725-736.

Lawrence, M.G., Kamber, B.S., 2006. The behaviour of the rare earth elements during estuarine mixing-revisited. Mar. Chem. 100 (1-2), 147-161.

Lea, D.W., Shen, G.T., Boyle, E.A., 1989. Coralline barium records temporal variability in equatorial Pacific upwelling. Nature 340 (6232), 373-376.

Leonard, N.D., Welsh, K.J., Lough, J.M., Feng, Y.X., Pandolfi, J.M., Clark, T.R., Zhao, J.X., 2016. Evidence of reduced mid-Holocene ENSO variance on the great barrier reef, Australia. Paleoceanography 31 (9), 1248-1260.

Lewis, S.E., Brodie, J.E., McCulloch, M.T., Mallela, J., Jupiter, S.D., Stuart Williams, H., Lough, J.M., Matson, E.G., 2012. An assessment of an environmental gradient using coral geochemical records, Whitsunday Islands, Great Barrier Reef, Australia. Mar. Pollut. Bull. 65 (4-9), 306-319.

Lewis, S.E., Lough, J.M., Cantin, N.E., Matson, E.G., Kinsley, L., Bainbridge, Z.T., Brodie, J.E., 2018. A critical evaluation of coral $\mathrm{Ba} / \mathrm{Ca}, \mathrm{Mn} / \mathrm{Ca}$ and $\mathrm{Y} / \mathrm{Ca}$ ratios as indicators of terrestrial input: new data from the Great Barrier Reef, Australia. Geochem. Cosmochim. Acta 237, 131-154.

Lewis, S.E., Shields, G.A., Kamber, B.S., Lough, J.M., 2007. A multi-trace element coral record of land-use changes in the Burdekin River catchment, NE Australia. Paleogeogr. Paleoclimatology Paleoecology 246 (2-4), 471-487.

Lough, J., Barnes, D., McAllister, F., 2002. Luminescent lines in corals from the Great Barrier Reef provide spatial and temporal records of reefs affected by land runoff. Coral Reefs 21 (4), 333-343.

Lough, J.M., 2011a. Great Barrier Reef coral luminescence reveals rainfall variability over northeastern Australia since the 17th century. Paleoceanography 26 (22).

Lough, J.M., 2011b. Measured coral luminescence as a freshwater proxy: comparison with visual indices and a potential age artefact. Coral Reefs 30 (1), 169-182.

Lough, J.M., Lewis, S.E., Cantin, N.E., 2015. Freshwater impacts in the central great barrier reef: 1648-2011. Coral Reefs 34 (3), 739-751.

Lough, J.M., Llewellyn, L.E., Lewis, S.E., Turney, C.S.M., Palmer, J.G., Cook, C.G., Hogg, A.G., 2014. Evidence for suppressed mid-Holocene northeastern Australian monsoon variability from coral luminescence. Paleoceanography 29 (6), 581-594.

Macdonald, R.K., Ridd, P.V., Whinney, J.C., Larcombe, P., Neil, D.T., 2013. Towards environmental management of water turbidity within open coastal waters of the Great Barrier Reef. Mar. Pollut. Bull. 74 (1), 82-94.

McCulloch, M., Fallon, S., Wyndham, T., Hendy, E., Lough, J., Barnes, D., 2003. Coral record of increased sediment flux to the inner Great Barrier Reef since European settlement. Nature 421 (6924), 727-730.

Montaggioni, L.F., Le Cornec, F., Corrège, T., Cabioch, G., 2006. Coral barium/calcium record of mid-Holocene upwelling activity in New Caledonia, South-West Pacific. Palaeogeogr. Palaeoclimatol. Palaeoecol. 237 (2-4), 436-455.

Moyer, R.P., 2012. A multiproxy record of terrestrial inputs to the coastal ocean using minor and trace elements $(\mathrm{Ba} / \mathrm{Ca}, \mathrm{Mn} / \mathrm{Ca}, \mathrm{Y} / \mathrm{Ca})$ and carbon isotopes $(\mathrm{C}, \Delta \mathrm{C})$ in a nearshore coral from Puerto Rico. Paleoceanography 27 (3).

Naqvi, S.A.S., Nagender Nath, B., Balaram, V., 1996. Signatures of rare-earth elements in banded corals of Kalpeni atoll - Lakshadweep archipelago in response to monsoonal variations. Indian J. Mar. Sci. 25, 1-4.

Nguyen, A.D., Zhao, J.x., Feng, Y.x., Hu, W.p., Yu, K.f., Gasparon, M., Pham, T.B., Clark, T.R., 2013. Impact of recent coastal development and human activities on Nha Trang Bay, Vietnam: evidence from a Porites lutea geochemical record. Coral Reefs 32 (1), 181-193.
Nothdurft, L.D., Webb, G.E., Bostrom, T., Rintoul, L., 2007. Calcite-filled borings in the most recently deposited skeleton in live-collected Porites (Scleractinia): implications for trace element archives. Geochem. Cosmochim. Acta 71 (22), 5423-5438.

Nozaki, Y., Zhang, J., Amakawa, H., 1997. The fractionation between Y and Ho in the marine environment. Earth Planet. Sci. Lett. 148 (1), 329-340.

Okai, T., Suzuki, A., Kawahata, H., Terashima, S., Imai, N., 2002. Preparation of a new geological survey of Japan geochemical reference material: coral JCp-1. Geostand. Newsl. 26 (1), 95-99.

Pandolfi, J.M., 2015. Incorporating uncertainty in predicting the future response of coral reefs to climate change. Annu. Rev. Ecol. Evol. Syst. 46 (1), 281-303.

Pandolfi, J.M., Bradbury, R.H., Sala, E., Hughes, T.P., Bjorndal, K.A., Cooke, R.G., McArdle, D., McClenachan, L., Newman, M.J.H., Paredes, G., Warner, R.R., Jackson, J.B.C., 2003. Global trajectories of the long-term decline of coral reef Ecosystems. Science 301 (5635), 955-958.

Perry, C.T., Smithers, S.G., Gulliver, P., 2013. Rapid vertical accretion on a 'young' shore-detached turbid zone reef: offshore Paluma Shoals, central Great Barrier Reef, Australia. Coral Reefs 32 (4), 1143-1148.

Prouty, N.G., Field, M.E., Stock, J.D., Jupiter, S.D., McCulloch, M., 2010. Coral Ba/Ca records of sediment input to the fringing reef of the southshore of Moloka'i, Hawai'i over the last several decades. Mar. Pollut. Bull. 60 (10), 1822-1835.

Prouty, N.G., Hughen, K.A., Carilli, J., 2008. Geochemical signature of land-based activities in Caribbean coral surface samples. Coral Reefs 27 (4), 727-742.

Quinn, K.A., Byrne, R.H., Schijf, J., 2004. Comparative scavenging of yttrium and the rare earth elements in seawater: competitive influences of solution and surface chemistry. Aquat. Geochem. 10 (1), 59-80.

Rodriguez-Ramirez, A., Grove, C.A., Zinke, J., Pandolfi, J.M., Zhao, J.-x., 2014. Coral luminescence identifies the pacific decadal oscillation as a primary driver of river runoff variability impacting the southern great barrier reef. PLoS One 9 (1), e84305.

Saha, N., Rodriguez-Ramirez, A., Nguyen, A.D., Clark, T.R., Zhao, J.X., Webb, G.E., 2018a Seasonal to decadal scale influence of environmental drivers on $\mathrm{Ba} / \mathrm{Ca}$ and $\mathrm{Y} / \mathrm{Ca}$ in coral aragonite from the southern Great Barrier Reef. Sci. Total Environ. 639, 1099-1109.

Saha, N., Webb, G.E., Zhao, J.-X., 2016. Coral skeletal geochemistry as a monitor of inshore water quality. Sci. Total Environ. 566-567, 652-684.

Saha, N., Webb, G.E., Zhao, J.-X., Leonard, N.D., Nguyen, A.D., 2018b. Influence of marine biochemical cycles on seasonal variation of $\mathrm{Ba} / \mathrm{Ca}$ in the near-shore coral Cyphastrea, Rat Island, southern Great Barrier Reef. Chem. Geol. 499, 71-83.

Saha, N., Webb, G.E., Zhao, J.-X., Nguyen, A.D., Lewis, S.E., Lough, J.M., 2019 Coral-based high-resolution rare earth element proxy for terrestrial sediment discharge affecting coastal seawater quality, Great Barrier Reef. Geochem. Cosmochim. Acta 254, 173-191.

Schaffelke, B., McAllister, F., Furnas, M., 2008. Water Quality and Ecosystem Monitoring Programme - Reef Water Quality Protection Programme; 3.7.2 Ext B: Marine Flood Plume Monitoring. Final Report 2007/2008 Australian Institute of Marine Science, Townsville.

Schroeder, T., Devlin, M.J., Brando, V.E., Dekker, A.G., Brodie, J.E., Clementson, L.A., McKinna, L., 2012. Inter-annual variability of wet season freshwater plume extent into the Great Barrier Reef lagoon based on satellite coastal ocean colour observations. Mar. Pollut. Bull. 65 (4-9), 210-223.

Sholkovitz, E., Shen, G.T., 1995. The incorporation of rare earth elements in modern coral. Geochem. Cosmochim. Acta 59 (13), 2749-2756.

Sinclair, D.J., 2005. Non-river flood barium signals in the skeletons of corals from coastal Queensland, Australia. Earth Planet. Sci. Lett. 237 (3), 354-369.

Sinclair, D.J., McCulloch, M.T., 2004. Corals record low mobile barium concentrations in the Burdekin River during the 1974 flood: evidence for limited Ba supply to rivers? Palaeogeogr. Palaeoclimatol. Palaeoecol. 214 (1), 155-174.

Tanzil, J.T.I., Goodkin, N.F., Sin, T.M., Chen, M.L., Fabbro, G.N., Boyle, E.A., Lee, A.C., Toh, K.B., 2019. Multi-colony coral skeletal Ba/Ca from Singapore's turbid urban reefs: relationship with contemporaneous in-situ seawater parameters. Geochem. Cosmochim. Acta 250, 191-208.

Taylor, R.B., Barnes, D.J., Lough, J.M., 1993. Simple models of density band formation in massive corals. J. Exp. Mar. Biol. Ecol. 167 (1), 109-125.

Taylor, R.B., Barnes, D.J., Lough, J.M., 1995. On the inclusion of trace materials into massive coral skeletons. 1. Materials occurring in the environment in short pulses. J. Exp. Mar. Biol. Ecol. 185 (2), 255-278.

Walther, B.D., Kingsford, M.J., McCulloch, M.T., 2013. Environmental records from great barrier reef corals: inshore versus offshore drivers. PLoS One 8 (10), e77091.

Webb, G.E., Kamber, B.S., 2000. Rare earth elements in Holocene reefal microbialites: a new shallow seawater proxy. Geochem. Cosmochim. Acta 64 (9), 1557-1565.

Wyndham, T., McCulloch, M., Fallon, S., Alibert, C., 2004. High-resolution coral records of rare earth elements in coastal seawater: biogeochemical cycling and a new environmental proxy. Geochem. Cosmochim. Acta 68 (9), 2067-2080.

Zhang, J., Nozaki, Y., 1996. Rare earth elements and yttrium in seawater: ICP-MS determinations in the east caroline, Coral Sea, and South Fiji basins of the western south Pacific Ocean. Geochem. Cosmochim. Acta 60 (23), 4631-4644.

Zhang, J., Nozaki, Y., 1998. Behavior of rare earth elements in seawater at the ocean margin: a study along the slopes of the Sagami and Nankai troughs near Japan. Geochem. Cosmochim. Acta 62 (8), 1307-1317. 